UNIVERSITY OF SZEGED FACULTY OF MEDICINE DEPARTMENT OF SURGERY

\title{
THE SIGNIFICANCE OF AXILLARY TREATMENT IN THE COMPLEX THERAPY FOR PATIENTS WITH BREAST CANCER
}

\author{
Ph.D. Thesis \\ Horváth Zoltán M.D.
}

Supervisor: György Lázár M.D., Ph.D., D.Sc.

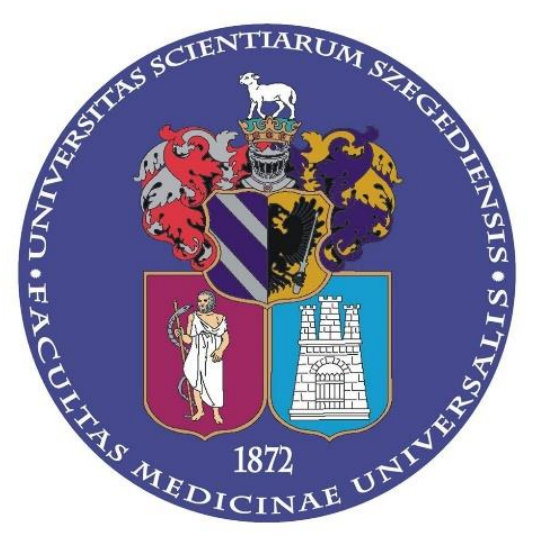

Szeged 


\section{CONTENTS}

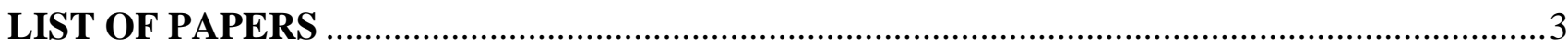

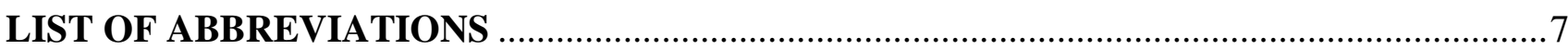

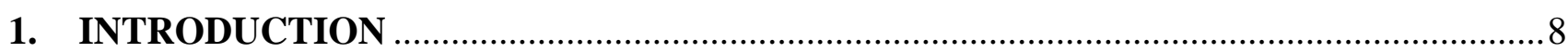

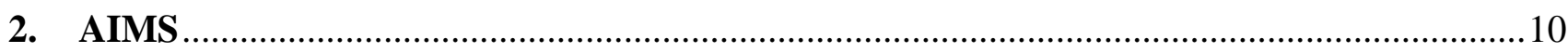

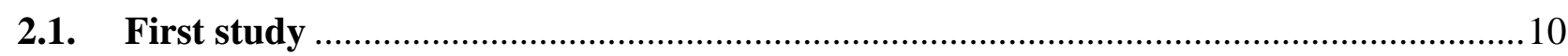

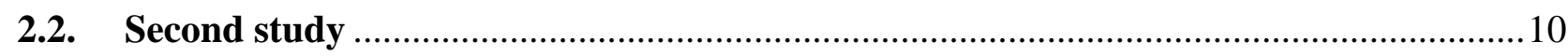

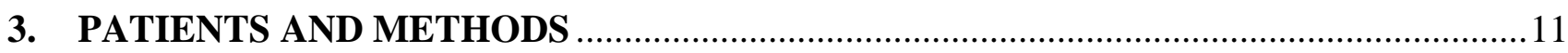

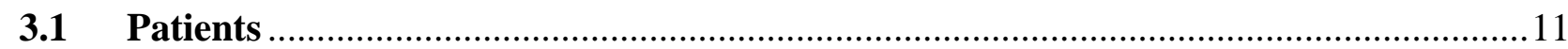

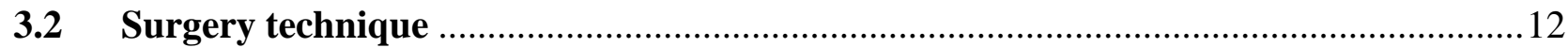

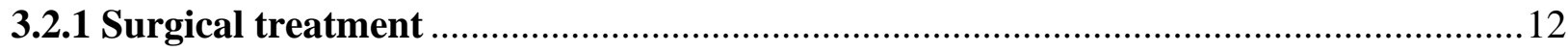

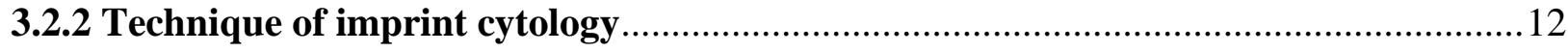

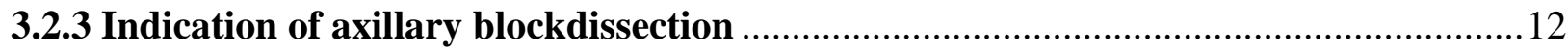

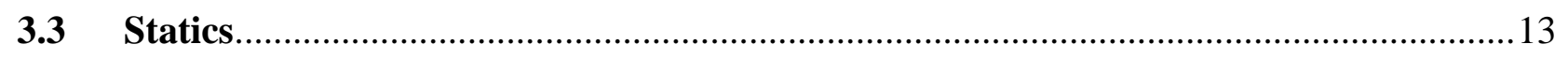

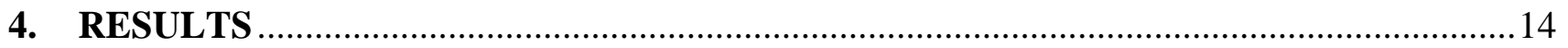

4.1. Is intraoperative touch imprint cytology indicated in the surgical treatment of early

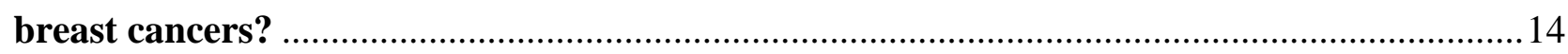

4.2. Is axillary lymph node dissection necessary for positive preoperative aspiration cytology

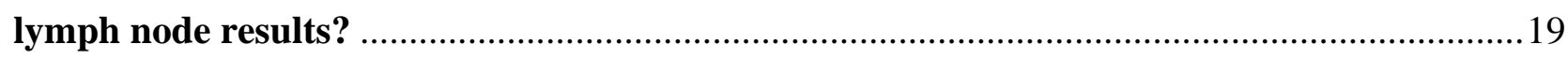

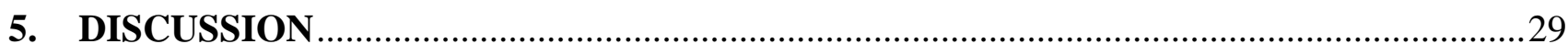

a) Is intraoperative touch imprint cytology indicated in the surgical treatment of early

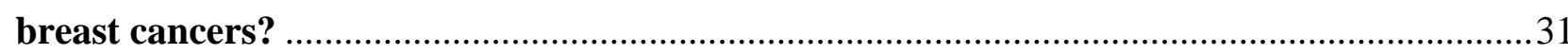

b) Is axillary lymph node dissection necessary for positive preoperative aspiration

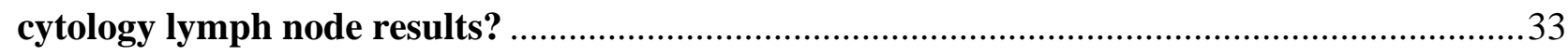

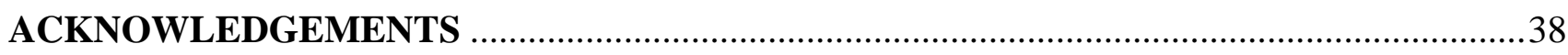

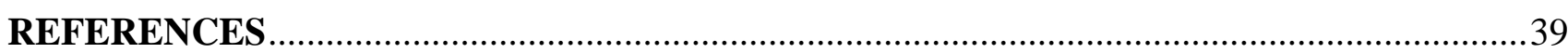




\section{LIST OF PAPERS}

\section{THIS DOCTORAL THESIS IS BASED ON THE FOLLOWING PUBLICATIONS:}

I. Horváth, Z ; Paszt, A ; Simonka, Z ; Látos, M ; Oláh, V ; Nagyszegi, D ; Kaizer, L ; Fejes, Z ; Hamar, S ; Csörgő, E ; Ormándi K ; Lázár M ; Lázár G. Is intraoperative touch imprint cytology indicated in the surgical treatment of early breast cancers? EUROPEAN JOURNAL OF SURGICAL ONCOLOGY $43: 7$ pp. 1252-1257. , 6 p. (2017) IF: 3,83

II. Horváth, Z. ; Paszt, A. ; Simonka, Z. ; Látos, M. ; Kaizer, L. ; Hamar, S. ; Vörös, A. ; Ormándi, K. ; Fejes, Z. ; Lázár, G. Is axillary lymph node dissection necessary for positive preoperative aspiration cytology lymph node results? EUROPEAN JOURNAL OF SURGICAL ONCOLOGY pii: S0748-7983(19)30923-0. doi: 10.1016/j.ejso.2019.10.043. (2019) IF: 3,379

Total impact factor of original papers directly related to the thesis: 7,209

\section{PUBLICATIONS RELATED TO THE TOPIC OF THE DISSERTATION:}

I. Wittmann, V ; Latos, M ; Horvath, Z ; Simonka, Z ; Paszt, A ; Lazar, G ; Csabai, M What contributes to long-term quality of life in breast cancer patients who are undergoing surgery? Results of a multidimensional study QUALITY OF LIFE RESEARCH 26 : 8 pp. 2189-2199. , 11 p. (2017) IF: 2,392

II. Látos, M ; Sándor, Z ; Kriston, P ; Havancsák, R ; Horváth, Z ; Paszt, A ; Simonka, Zs ; Lázár, Gy ; Csabai, M Associations Between a Sedentary Lifestyle and Negative Mood State and the Risk of Breast Cancer In: Benkő, Zsuzsanna; Modi, Ishwar; Tarkó, Klára (szerk.) Leisure, Health and Well-Being : A Holistic Approach Cham (Svájc), Svájc : Palgrave Macmillan, (2017) pp. 99-114. , 16 p.

III. Wittmann, V ; Látos, M ; Horváth, Z ; Simonka, Zs ; Paszt, A ; Lázár, Gy ; Csabai, M Emlődaganatos nőbetegek komplex támogató terápiája. Egy pszichológiai intervenciós kutatás előzetes eredményei ORVOSI HETILAP 160: 18 pp. 700-709. , 10 p. (2019) IF: 0,53

Total impact factor of original papers related to the thesis: 2,922 


\section{LECTURES RELATED TO THE TOPIC OF THE DISSERTATION:}

I. Horváth, Z ; Paszt, A ; Simonka, Zs ; Ábrahám, Sz ; Mészáros, P ; Hamar, S ; Kaizer, L ; Csörgő, E ; Ormándi, K ; Lázár, M ; Lázár, Gy. Az imprint citológia szerepe a korai emlőrákok műtéti kezelésében. MAGYAR SEBÉSZET 63 p. 209 (2010)

II. Horváth, Z ; Hamar, S ; Kaizer, L ; Paszt, A ; Simonka, Zs ; Végh, E ; Csörgő, E; Lázár, M ; Ormándi, K ; Lázár, Gy Az imprint cytologia szerepe a korai emlőrákok mütéti kezelésében MAGYAR SEBÉSZET 65 : 4 pp. 250-250. , 1 p. (2012)

III. M, Látos ; P, Kriston ; Z, Horváth ; Gy, Lázár ; A, Paszt ; Zs, Simonka ; M, Csabai Associations of sedentary lifestyle and negative mood state with the risk of breast cancer In: 'Leisure, Health and Well-Being' : Mid-term Conference of Research Committee on Sociology of Leisure (2013) pp. 37-38. , 2 p.

IV. Látos, M ; Horváth, Z ; Lázár, Gy ; Paszt, A ; Simonka, Zs ; Csabai, M Pre-és posztoperatív pszichológiai állapot feltárása emlődaganattal műtött nők körében In: Tisljár-Szabó, Eszter (szerk.) XIII. Magatartástudományi Napok : Magatartástudományok a betegellátásban Debrecen, Magyarország (2013) pp. 22-23. , 2 p.

V. Horváth, Z ; Paszt, A ; Simonka, Zs ; Látos, M ; Végh, E ; Hamar, S ; Kaizer, L ; Csörgő, E ; Lázár, M ; Ormándi, K ; Lázár Gy. Az imprint citológia hatékonyságának vizsgálata a korai emlődaganatok mütéti kezelésében MAGYAR SEBÉSZET 67 : 3 pp. 170-170. , 1 p. (2014)

VI. Horváth, Z ; Simonka, Zs ; Paszt, A ; Látos, M ; Kahán, Zs ; Uhercsák, G ; Varga, L ;

Ormándi, K ; Vörös, A ; Lázár, Gy Neoadjuváns chemoterápia utáni mastectomia: esetbemutatás In: MST Fiatal Sebészek Szekciójának II. kongresszusa (2014) pp. 14-14. , 1 p.

VII. Horváth, Z ; Simonka, Zs ; Látos, M ; Lázár, Gy Mastectomia előtti neoadjuváns chemoterápia hatása: esetbemutatás (2014) Elhangzott előadás, Fiatal Sebészek Szekciójának II. Kongresszusa, Balatonalmádi, 2014. április 4-6.,

VIII. Horváth, Z ; Simonka, Zs ; Paszt, A ; Látos, M ; Kahán, Zs ; Uhercsák, G ; Varga, L ; Ormándi, K ; Vörös, A ; Lázár, Gy Neoadjuváns chemoterápia utáni mastectomia MAGYAR SEBÉSZET $67: 2$ pp. 68-68. , 1 p. (2014)

IX. Horváth, Z ; Paszt, A ; Simonka, Zs ; Oláh, V ; Nagyszegi, D ; Kaizer, L ; Hamar, S ; Csörgő, E ; Ormándi, K ; Lázár, M ; Lázár Gy. Az imprint citológia jelentőségének átgondolása a rosszindulatú emlődaganatok sebészetében In: VI. Szegedi Emlőrák Szimpózium Szeged, Magyarország (2015) pp. 35-35. , 1 p. 
X. Wittmann, V ; Látos, M ; Horváth, Z ; Paszt, A ; Simonka, Zs; Lázár, Gy; Csabai, M Emlődaganatos nőbetegek longitudinális vizsgálata az életminőség, a poszttraumatikus növekedés, a testkép és az egészségmagatartás összefüggésében In: Vargha, András (szerk.) Múlt és jelen összeér : A Magyar Pszichológiai Társaság XXV. Jubileumi Országos Tudományos Nagygyülése Kivonatkötet Budapest, Magyarország : Magyar Pszichológiai Társaság, (2016) pp. 233-234. , 2 p.

XI. Forrai, G ; Lazar, G ; Cserni, G ; Polgar, C ; Horvath, Z ; Kahan, Z ; Kasler, M ; Svebis, M Levél az emlőrák felismerésétől az emlőrákos betegek rehabilitációjáig tartó folyamat javításának érdekében MAGYAR SEBÉSZET 69 : 4 pp. 203-207. , 5 p. (2016)

XII. Wittmann, V ; Látos, M ; Horváth, Z; Simonka, Zs ; Paszt, A ; Lázár, Gy Mi határozza meg az emlődaganatos nőbetegek hosszú távú életminőségét? MAGYAR SEBÉSZET $70: 2$ pp. 183-183. , 1 p. (2017)

XIII. Wittmann, V ; Látos, M ; Horváth, Z ; Simonka, Zs ; Paszt, A ; ifj Lázár, Gy ; Csabai, M. Mi határozza meg az emlődaganatos nőbetegek hosszú távú életminőségét? Egy többdimenziós kutatás eredményei In: Lippai, Edit (szerk.) Személyes Tér - Közös Világ : A Magyar Pszichológiai Társaság XXVI. Országos Tudományos Nagygyülése : Kivonatkötet Budapest, Magyarország : Magyar Pszichológiai Társaság, (2017) pp. 74-74. , 1 p.

XIV. Wittmann, V ; Látos, M ; Horváth, Z ; Simonka, Zs ; Paszt, A ; ifj Lázár, Gy ; Csabai, M. Mi határozza meg az emlődaganatos nőbetegek hosszú távú életminőségét? Egy többdimenziós kutatás eredményei In: VII. Szegedi Emlőrák Szimpózium Szeged, Magyarország (2017) pp. 68-68. , 1 p.

XV. Horváth, Z ; Paszt, A ; Simonka, Zs ; Látos, M ; Oláh, V ; Nagyszegi, D ; Kaizer, L ; Fejes, Zs ; Hamar, S ; Csörgő, E ; Ormándi K ; Lázár M ; Lázár G. Indokolt az impront citológia intraoperatív alkalmazása korai emlődaganatok sebészi kezelésében? MAGYAR SEBÉSZET $70: 2$ pp. 167-167. , 1 p. (2017) 


\section{PUBLICATIONS NOT RELATED TO THE THESIS:}

XVI. Simonka, Z ; Paszt, A ; Géczi, T ; Ábrahám, S ; Tóth, I ; Horváth, Z ; Pieler, J ; Tajti, J ; Varga, A ; Tiszlavicz, L ; Németh, I ; Izbéki, F ; Rosztóczy, A, Wittmann, T ; Lázár, Gy. Refluxbetegség és Barrett-nyelőcső miatt mütétre kerülő betegek összehasonlító vizsgálata: Comparison of surgical patients with gastroesophageal reflux disease and Barrett's esophagus MAGYAR SEBÉSZET 67: 5 pp. 287-296. , 10 p. (2014)

XVII. Látos, M ; Lázár, Gy ; Havancsák, R ; Pócza-Véger, P ; Horváth, Z; Csabai, M A projektív rajztesztek alkalmazásának lehetőségei transzplantált páciensek körében In: Papp, Barbara (szerk.) Pszichológiai kutatások : A Nemzeti Kiválóság Program ösztöndíjasainak publikációi: Pécsi Tudományegyetem Pszichológia Intézet Pécs, Magyarország : [s. n.], (2014) pp. 29-38., 10 p.

XVIII. Urban, E ; Horvath, Z ; Soki, J ; Lazar, G First Hungarian case of an infection caused by multidrug-resistant Bacteroides fragilis strain. ANAEROBE 31 pp. 55-58. , 4 p. (2015) IF: 2,81

XIX. M, Látos ; Á, Devecsery ; Gy, Lázár ; Z, Horváth ; E, Szederkényi ; P, Szenohradszky ; Márta, Csabai The role of body image integrity and posttraumatic growth in kidney transplantation: A 3-year longitudinal study HEALTH PSYCHOLOGY OPEN 2015 PMC Full text Paper: 2055102915581214 , 8 p. (2015)

XX. Látos, M ; Devecsery, Á ; Lázár, Gy ; Horváth, Z ; Szenohradszky, P ; Szederkényi, E ; Csabai, M A testkép komplexitása és a szervátültetés sikeressége. Vesetranszplantált páciensek longitudinális vizsgálata: Body boundaries and the successful organ transplantation. Longitudinal study of renal transplant patients MAGYAR PSZICHOLÓGIAI SZEMLE 70: 2 pp. 313-325., 13 p. (2015)

XXI. Látos, M ; Lázár, G ; Horváth, Z ; Wittmann, V ; Szederkényi, E ; Hódi, Z ; Szenohradszky, $\mathrm{P}$; Csabai, M Psychological rejection of the transplanted organ and graft dysfunction in kidney transplant patients TRANSPLANT RESEARCH AND RISK MANAGEMENT 8 pp. 15-24., 10 p. (2016) IF: 0,290

Total impact factor of original papers not related to the thesis: 3,1

\section{Cumulative impact factor: $\mathbf{1 3 , 2 3 1}$}




\section{LIST OF ABBREVIATIONS}

\begin{tabular}{|c|c|c|}
\hline AATRM & - & Agència d'Avaluació de Tecnologia i Recerca Mèdiques \\
\hline $\mathrm{ABD}$ & - & axillary blockdissection \\
\hline ACOSOG & - & American College of Surgeons Oncology Group \\
\hline AMAROS & - & After Mapping of the Axilla: Radiotherapy or Surgery? \\
\hline EORTC & - & European Organization for Research and Treatment of Cancer \\
\hline ER & - & estrogen receptor \\
\hline FNAC & - & fine-needle aspiration cytology \\
\hline IBCSG & - & International Breast Cancer Study Group \\
\hline ITC & - & isolated tumor cells \\
\hline NCCN & - & National Comprehensive Cancer Network \\
\hline PR & - & progesteron receptor \\
\hline ROLL & - & Radioguided Occult Lesion Localisation \\
\hline SD & - & standard deviation \\
\hline SLNB & - & sentinel lymph node biopsy \\
\hline TIC & - & touch imprint cytology \\
\hline TNBC & - & triple-negative breast cancer \\
\hline $\mathrm{UH}$ & - & ultrasound \\
\hline
\end{tabular}




\section{INTRODUCTION}

Complex treatment of patients with breast cancer, including surgical treatment, has significantly changed over the past 100 years. Due to the development in diagnostics, a better understanding of the biological characteristics of tumours and the expansion of treatment options in oncology, super-radical resection surgery - applied initially - has been replaced by increasingly less invasive interventions, and the aim to conserve the breast became generally accepted.

Axillary lymph node dissection used to constitute an integral part of the onco-surgical treatment of breast cancer. In the past 25 years, there have also been significant changes in the diagnostics and treatment of the axilla. Due to the introduction of sentinel lymph node biopsy (SLNB) in 1993, axillary block dissection (ABD), which is characterised by a significant morbidity rate, became safely avoidable in a significant proportion of patients. Similarly, staging, thus complex oncology treatment of breast cancer also became significantly more accurate. ${ }^{1,2,3}$ The introduction of SLNB also brought about the intraoperative assessment of the sentinel lymph node, which reduced the number of surgeries in two sittings, and, therefore, patient burden and surgery costs. ${ }^{4,5,6,7}$

Initially, if preoperative assessment was negative, but intraoperative or final histological examination found a metastasis in the sentinel lymph node, axillary block dissection was considered necessary. Clinical studies later showed that performing SLNB is sufficient even in the presence of a lymph node containing a micrometastasis or an isolated tumour cell (e.g. International Breast Cancer Study Group (IBCSG) 23-01, Agència d'Avaluació de Tecnologia i Recerca Mèdiques (AATRM) 048/13/2000). ${ }^{9,10}$ Milestone findings of the Z0011 study of the American College of Surgeons Oncology Group (ACOSOG) showed that axillary block dissection is not necessary even in the presence of up to 2 positive lymph nodes containing macrometastases, if this complies with the inclusion criteria of the study. ${ }^{8,9,10}$ The findings of study of the European Organization for Research and Treatment of Cancer (EORTC), titled After Mapping of the Axilla: Radiotherapy or Surgery? (AMAROS) show that even in patients who underwent mastectomy and have a sentinel lymph node that is proven to be metastatic, axillary block dissection is avoidable, and axillary irradiation and close follow-up is sufficient. ${ }^{11,12}$

Currently accepted international guidelines in breast cancer recommend axillary block dissection, if preoperative assessments confirm axillary metastasis, and the patient undergoes surgery with or without prior neoadjuvant therapy. ${ }^{13,14,15,16}$ 
Multiple studies show that targeted axillary irradiation is a therapeutic alternative to axillary block dissection. ${ }^{11,12,17}$ Patients increasingly and rightfully demand a better understanding of treatment alternatives and more control over which one to choose. The reduction in the indication of axillary block dissection and appearance of irradiation as a therapeutic alternative, and also participation of patients in therapeutic decision-making warranted the rethinking of the application of intraoperative lymph node diagnostics and imprint cytology.

However, patients where preoperative assessment already confirms axillary lymph node metastasis constitute a separate treatment group. In these cases, axillary block dissection continues to be the surgical recommendation. Axillary ultrasound plays a fundamental role in screening axillary metastasis, and a positive scan necessitates aspiration cytology. ${ }^{18}$ The sensitivity of axillary ultrasound ranges from 25 to $71 \%$, depending on the immunohistochemical status of the tumour. Combined with fine-needle aspiration cytology (FNAC), its sensitivity increases to $70-80 \% .^{19,20,21,22}$

In cases with a positive lymph node by aspiration cytology, a proportion of patients receive systemic neoadjuvant therapy. Multinational results indicate that in these cases, a significant proportion of patients experience complete axillary pathologic regression..$^{23,24,25}$

Similarly, it is also known that in a certain proportion of patients, only the sentinel lymph node contains a metastasis. An American study published in 2017 confirmed that if the primary tumour is $\leq 2 \mathrm{~cm}$ as measured by breast ultrasound, aspiration cytology confirms $\leq 1$ positive axillary lymph node, and the patient does not receive neoadjuvant therapy, ABD is not necessarily justified, and SLNB is recommended instead. ${ }^{26}$ 


\section{AIMS}

\subsection{First study}

Introduced 20 years ago, lymph node biopsy significantly reduced the number of radical surgical interventions - axillary block dissections - in the treatment of early breast cancer. In the meantime, intraoperative processing of sentinel lymph nodes became increasingly widespread, as its use helped avoid surgery in two sittings. ${ }^{27,28}$

Over the past years, surgical treatment of the axilla, primarily in terms of the necessity of axillary block dissections, has considerably changed. Results of several prospective studies indicate that $\mathrm{ABD}$ is not warranted for sentinel lymph nodes containing positive, isolated tumour cells (ITC, $\leq 0.2 \mathrm{~mm})$, and micrometastases $(\leq 2 \mathrm{~mm})$, and adjuvant therapy is sufficient (systemic therapy, whole-breast irradiation). Based on the ACOSOG Z0011 study published in 2011, axillary block dissection is not necessary even in T1 or T2 breast cancer, following wide local excision, or sentinel lymph node biopsy showing no more than 1 or 2 macrometastases in sentinel lymph nodes. ${ }^{29,30}$

All these factors warranted the rethinking of the application of routine imprint cytology. In this work, we retrospectively looked at the findings of imprint cytology assessments performed in our institute and also analysed these in the context of the new international guidelines in axillary treatment.

\subsection{Second study}

In the second study, we looked for correlations between axillary ultrasound and clinicopathological factors, which help us predict the presence and severity of axillary metastasis in order to decide in advance - in light of the results of preoperative assessments the cases in which axillary block dissection can be avoided.

Our investigation aimed to find correlations between pre-and intraoperative assessments and clinicopathological factors, which allows us to assess not only the presence of axillary metastasis, but also its severity (mild or severe). Our additional goal was to decide in advance - based on pre-and intraoperative assessments - which cases require axillary block dissection and which cases necessitate sentinel lymph node biopsy only. 


\section{PATIENTS AND METHODS}

\subsection{Patients}

The study involved the retrospective analysis of the pre-, intra- and postoperative data of 2671 cases involving surgery due to early invasive breast cancer at the Department of Surgery, Faculty of Medicine, University of Szeged between 1 January 2007 and 31 December 2017. Mandatory parts of the complex breast assessment included physical examination, ultrasonography and mammography. If a suspicious, metastatic axillary lymph node was noticed during axillary ultrasound, aspiration cytology was always performed. If aspiration cytology confirmed the presence of a metastasis, a certain portion of patients also received systemic neoadjuvant therapy.

In our first study, we looked at the sensitivity and specificity of the imprint cytology of the sentinel lymph node from 1168 patients who underwent surgery due to invasive breast cancer between 1 May 2008 and 31 December 2014. In addition, we retrospectively analysed the method in the context of the ACOSOG ZOO11 study, accepted international guidelines and consensus conference guidelines. ${ }^{8,13,14,15,16,31}$

In the second study, we looked at the pre- and postoperative data of 2671 cases involving surgery due to early invasive breast cancer between 1 January 2007 and 31 December 2017. We looked for correlations between preoperative axillary assessments and clinicopathological factors, which allowed us to predict not only the presence of axillary metastasis, but also its severity (mild or severe). 


\subsection{Surgery technique}

\subsubsection{Surgical treatment}

In the surgical treatment of invasive breast tumours, our aim in general is to achieve oncologically adequate - tumour free - resection edges. Our goal was to provide locoregional tumour control and precise locoregional staging. With the aesthetic outcome also taken into consideration, breast-conserving surgery was performed whenever possible.

Sentinel lymph nodes were removed with the double tracer method published by Albertini in 1996. ${ }^{32}$ ROLL (radio-guided occult lesion localisation) and dual labelling were used to localise breast tumours and the sentinel lymph node. At least 4 hours before the surgery, isotope $(99 \mathrm{mTc})$ labelled human colloidal albumin was administered into the lesion, which was followed by lymphoscintigraphy to determine the projection of the sentinel lymph node and that of the lymphatic drainage. As a first step during surgery, Patentblau dye was administered around the areola, and then manual gamma probe was used to remove the tumour and the sentinel lymph node during the same procedure approximately 10 minutes later.

\subsubsection{Technique of imprint cytology}

The cut surface of the fresh sample prepared from a lymph node $(250 \mu \mathrm{m}$ slices $)$ was pressed on a slide, and then an impression smear was prepared. The resulting imprint cut surfaces were fixed in $95 \%$ ethanol for 5-6 seconds, and the samples were evaluated after hematoxylin eosin staining.

\subsubsection{Indication of axillary blockdissection}

In the first study (between 2008 and 2014), in agreement with the Hungarian guidelines in force, we performed $\mathrm{ABD}$ if either the preoperative assessments (ultrasound-guided FNAC/core biopsy), or intraoperative imprint cytology, or the final pathologic examination of the sentinel lymph node confirmed lymph node metastasis.

Later, from 2014, imprint cytology was no longer used, and, in agreement with the guideline changes, if metastasis (macrometastasis) is found in > $2 \mathrm{SLN}$ and/or the patient does not meet the inclusion criteria of the Z-0011 study. ABD is also performed in cases with mastectomy and SLNB, if no postoperative radiation therapy is planned, and SLN (even one lymph node) contains a macrometastasis. If ultrasound-guided FNAC/core biopsy or SLNB prior to neoadjuvant 
(primary systemic) therapy, or SLNP performed after neoadjuvant (primary systemic) therapy confirms lymph node metastasis, ABD is performed in these cases also.

Neoadjuvant therapy was administered in accordance with the current international practice, primarily to be able to remove tumours that were originally found to be oncologically inoperable, and to be able to perform breast conserving surgery instead of mastectomy. Indication of neoadjuvant therapy is established from the cT2 and cN0 or c/pN1 status, and from the cT14/cTx N2 status (the latter: unknown primary breast tumour). Regular physical and imagining examinations were performed to evaluate the efficacy of therapy, and in cases where there was a possibility for breast conserving therapy, clip labelling of the tumour was also performed at the beginning of the therapy.

\subsection{Statics}

IBM SPSS Statistics v22 program was used for statistical analysis in our study. Continuous variables were presented as mean and standard deviation, categorical variables were presented as case number and percentages. Chi square test followed by logistic regression were used to evaluate cumulative effect of the variables on the axillary status. The difference was considered to be statistically significant in cases where $\mathrm{p}<0.05$. 


\section{RESULTS}

\subsection{Is intraoperative touch imprint cytology indicated in the surgical treatment of early breast cancers?}

In our Department, TIC was performed in 1168 cases for invasive breast tumor during the period under examination (Table 1). The average age of the patients was 58.63 (25-88) years. TIC was positive in 202 cases in 17.29\% (202/1168) of the cases. A total of 2101 lymph nodes were sent for imprint cytology, which is an average of 1.8 (1-6) lymph nodes per patient, and 348 were confirmed positive with final histological processing of the sample.

Table 1: Pathological characteristics of the tumors:

\begin{tabular}{|c|c|c|c|c|c|c|c|c|c|c|}
\hline & Number of cases & IDC & ILC & Other & ER (+) & PR (+) & ER+PR (+) & Gr. I. & Gr. II. & Gr. III. \\
\hline Total.: & 1168 & 760 & 141 & 267 & 937 & 801 & 788 & 200 & 565 & 352 \\
\hline$\%$ & $100 \%$ & $65 \%$ & $12 \%$ & $23 \%$ & $80.2 \%$ & $68.6 \%$ & $67.5 \%$ & $17.90 \%$ & $50.60 \%$ & $31.50 \%$ \\
\hline
\end{tabular}

IDC: invasive ductal carcinoma, ILC: invasive lobular carcinoma, ER: estrogen receptor, PR: progesterone receptor

During a final histological examination of the samples, metastasis was found in 149 additional previously (intraoperatively) negative sentinel lymph nodes (false negative cases: $149 / 1168$ [12.75\%]), and metastasis was not confirmed in three cases found to be positive with imprint cytology (false positive cases: 3/149 [0.25\%]). The sensitivity of the imprint cytology was $57.18 \%$, with a specificity of $99.63 \%$ (Table 2 ).

A total of 202 axillary block dissections were performed in one session, and then 80 block dissections were performed on a separate occasion. In 64 cases, an ABD was not performed, as the patient had not given his consent for the intervention, the patient had chosen adjuvant chemotherapy, or the oncoteam had not recommended additional surgery due to the presence of micrometastasis. 
Table 2. Imprint cytology results (1 May 2008-31 Dec 2014)

\begin{tabular}{|c|c|c|}
\hline & Total: & $\%$ \\
\hline Number of patients: & 1168 & 100 \\
\hline \multicolumn{3}{|l|}{ Imprint cytology results: } \\
\hline intraoperative (positive) & 202 & 17.3 \\
\hline intraoperative (negative) & 966 & 82.7 \\
\hline false negative & 149 & 12.76 \\
\hline false positive & 3 & 0.24 \\
\hline Number of positive final histological examinations: & 348 & 29.79 \\
\hline Number of negative final histological examinations: & 820 & 70.21 \\
\hline \multicolumn{3}{|l|}{ Type of surgery: } \\
\hline excision & 883 & 75.6 \\
\hline mastectomy & 285 & 24.4 \\
\hline Average tumor size $(\mathrm{mm})$ : & 19.61 & \\
\hline Average number of SLNBs: & 1.8 & \\
\hline ABDs & 284 & 24.32 \\
\hline in one session & 204 & 17.47 \\
\hline supplementary & 80 & 6.85 \\
\hline
\end{tabular}

At that point, patients meeting the inclusion criteria for the Z0011 study and seven patients that could not be classified in this group were excluded from the positive cases by intraoperative examination, metastasis smaller than $2 \mathrm{~mm}$ was confirmed in these cases (ITC, micrometastasis, Tables 3-4), and then the sensitivity and specificity of the method were recalculated. 
Table 3: Patients meeting the criteria for the Z0011 study and with a positive imprint cytology

\begin{tabular}{lcc}
\hline & Total: & $\mathbf{\%}$ \\
\hline Number of patients & 117 & 100 \\
\hline Imprint cytology results: & & \\
\hline Positive & 116 & 99.15 \\
\hline Negative & 0 & 0.85 \\
\hline False negative & 1 & 0.85 \\
\hline False positive & 116 & \\
\hline Number of final, positive histological examinations: & & \\
\hline Type of surgery: & 117 & 100 \\
\hline excision & 0 & 0 \\
\hline mastectomy & 20.56286 & \\
\hline Average tumor size (mm): & 1.97 & \\
\hline Average number of SLNBs: & \multicolumn{2}{c}{} \\
\hline ABDs & 2 & 111 \\
\hline Performed in one session & 4 & 3.42 \\
\hline Supplementary & & \\
\hline Not performed & & \\
\hline
\end{tabular}

*Axillary block dissection was not performed in four cases when a patient made a request in advance to that effect or in the presence of micrometastases. 
Table 4: Results modified in accordance with the criteria

\begin{tabular}{ccccc}
\hline & $\begin{array}{c}\text { Cases } \\
\text { (all cases) }\end{array}$ & $\begin{array}{c}\text { Cases not meeting } \\
\text { Z001ing } \\
\text { Zriteria }\end{array}$ & $\begin{array}{c}\text { Z0011 criteria but } \\
\text { involving } \\
\text { micrometastasis }\end{array}$ & $\begin{array}{c}\text { Results } \\
\text { recalculated }\end{array}$ \\
\hline Number of patients & 1168 & 117 & 7 & 1168 \\
\hline Imprint & & & & 78 \\
\hline Positive & 202 & 117 & 7 & 966 \\
\hline Negative & 966 & 0 & 0 & 225 \\
\hline Final histology & & & & 2 \\
\hline Positive & 348 & 116 & 7 & 149 \\
\hline False positive & 3 & 1 & 0 & \\
\hline False negative & 149 & 0 & 0 & \\
\hline
\end{tabular}

After screening, 76 positive, two false positive, 149 false negative and 966 negative cases were found in the repeated imprint cytology group. Sensitivity was $34.23 \%$, and specificity was $99.76 \%$ (Table 4).

It can be seen based on the Table 5 that axillary block dissection was performed in 284 cases, but, based on the new guidelines, only 105 cases were indicated. 179 cases, that is, $15.32 \%$ of the cases, were performed unnecessarily.

Table 5. Distribution of axillary block dissections

\begin{tabular}{|c|c|c|c|}
\hline & & Total: & Total number of ABDs: \\
\hline \multirow{2}{*}{ Imprint } & Supplementary ABDs & 80 & \multirow{2}{*}{284} \\
\hline & ABDs performed in one session & 204 & \\
\hline \multirow{2}{*}{$\begin{array}{c}\text { Positive cases } \\
\text { according to Z0011 } \\
\text { criteria }\end{array}$} & Supplementary ABDs & 2 & \multirow[t]{2}{*}{114} \\
\hline & ABDs performed in one session & 112 & \\
\hline \multirow{2}{*}{$\begin{array}{c}\text { False negative cases } \\
\text { according to } \\
\text { Z0011 criteria } \\
\end{array}$} & Supplementary ABDs & 56 & \multirow{2}{*}{58} \\
\hline & ABDs performed in one session & 2 & \\
\hline \multirow{2}{*}{$\begin{array}{c}\text { Cases not meeting } \\
\text { Z0011criteria but } \\
\text { involving } \\
\text { micrometastasis }\end{array}$} & Supplementary ABDs & 0 & \multirow[t]{2}{*}{7} \\
\hline & ABD performed in one session & 7 & \\
\hline \multirow{2}{*}{ Total } & Supplementary ABDs & 22 & \multirow{2}{*}{105} \\
\hline & ABDs performed in one session & 83 & \\
\hline
\end{tabular}


As the results were processed, the average size of the metastases and the distribution of micro- and macrometastases in false negative and positive cases were examined as well (Table 6). In positive cases, the average size of the micrometastases was $1.52 \mathrm{~mm}$, while that of the macrometastases was $8.33 \mathrm{~mm}$. The average size of the micrometastases was $1.1 \mathrm{~mm}$, while that of the macrometastases was $4.79 \mathrm{~mm}$ in the false negative group. Therefore, it can be concluded that imprint cytology cannot be considered a sensitive intervention for surgeries on smaller metastases.

Table 6. Lymph node metastases in false negative and false positive cases

\begin{tabular}{|c|c|c|c|c|c|}
\hline & $\begin{array}{c}\text { Sizes of } \\
\text { metastases } \\
\quad(\mathbf{m m})\end{array}$ & $\begin{array}{l}\text { Number of } \\
\text { metastases }\end{array}$ & $\begin{array}{c}\text { Distribution } \\
\text { in \% of all } \\
\text { metastases }\end{array}$ & $\begin{array}{c}\text { Distribution } \\
\text { in \% of all } \\
\text { micro- } \\
\text { metastases }\end{array}$ & $\begin{array}{c}\text { Distribution in } \\
\% \text { of all } \\
\text { macro- } \\
\text { metastases }\end{array}$ \\
\hline \multicolumn{6}{|l|}{ Positive cases: } \\
\hline micrometastases & 1.52 & 13 & 3.73 & 15.85 & \\
\hline macrometastases & 8.33 & 187 & 53.58 & & 70.3 \\
\hline \multicolumn{6}{|l|}{ False negative cases: } \\
\hline micrometastases & 1.1 & 69 & 19.77 & 84.15 & \\
\hline macrometastases & 4.79 & 80 & 22.92 & & 29.7 \\
\hline
\end{tabular}




\subsection{Is axillary lymph node dissection necessary for positive preoperative aspiration cytology lymph node results?}

In our second study, we analysed the data of 2671 patients who underwent surgery due to malignant breast cancer at the Department of Surgery of University of Szeged between 1 January 2007 and 31 December 2017. Preoperative examinations (axillary ultrasound, aspiration cytology sampling) confirmed axillary metastasis in 190 cases, where axillary block dissection was performed after neoadjuvant treatment. In our study, we compared the clinicopathological findings (histological, immunohistochemical status, tumour location, preand postoperative tumour size, number of positive tumours observed, lymph node size as described by ultrasound, neoadjuvant treatment) with lymph node status (N0-1 or N2-3, Z1 or $\mathrm{Z} 2$ - cases with a maximum of two or more metastatic lymph nodes), sorting patients into either the group that received or the group that did not receive neoadjuvant treatment, and we looked into which perioperative examination finding allows us to predict the presence of a lymph node with a maximum of 2 or 3 metastases in the axilla.

Pre- and postoperative data of 2671 cases where surgery was performed due to early invasive breast tumour were evaluated in the Department of Surgery, Faculty of Medicine, University of Szeged between 1 January 2007 and 31 December 2017.

The average age of the patients was 59.73 years (25-93). In 260 cases, axillary ultrasound suggested a metastatic lymph node; therefore, aspiration cytology sampling was performed, and in 190 cases (average age: 60.31 years, 29-89), pathology reports suggested metastasis. In these cases, ALND was performed. The average number of lymph nodes removed was 13.49 .

False positive results were found in $22(16.8 \%)$ of the 131 aspiration cytology examinations in patients not receiving neoadjuvant therapy. Based on the final histological examination of the axillary lymph nodes, 76 (58\%) patients were confirmed to be stage N0-1 and 55 (42\%) patients were stage N2-3.

No significant correlation was found between the preoperatively examinable clinicopathological parameters and the axillary lymph node status for patients not receiving neoadjuvant therapy. 
Neoadjuvant therapy was administered in 59 cases, and in $23(39 \%)$ of these cases, complete axillary pathological remission was confirmed. Based on the final histological examination of the axillary lymph nodes, $40(68 \%)$ patients were stage in N0-1, and $19(32 \%)$ patients were in stage $\mathrm{N} 2-3$.

The results of the histological examinations, the immunohistochemistry status, the location of the tumour, and the number of the positive lymph nodes detected by the ultrasound examination showed no correlation with the final histological status of the lymph node. If preoperative ultrasound examinations find that the primary breast tumour is $\leq 20 \mathrm{~mm}$ ( $\mathrm{p}=$ 0.002) or the positive lymph node is $\leq 15 \mathrm{~mm}$ ( $\mathrm{p}=0.04)$, the status of the axillary lymph nodes will likely be stage N0-1; therefore, a maximum of 3 positive axillary lymph nodes are present (Tables 7 and 8).

Table 7: Relation of preoperative imaging results to final lymph node disease burden in patients receiving neoadjuvant therapy - I - Chi square test.

\begin{tabular}{|c|c|c|c|}
\hline Neoadj. & $\begin{array}{c}\text { N0-1 } \\
(\mathrm{n}=40)\end{array}$ & $\begin{array}{c}\mathrm{N} 2-3 \\
(\mathrm{n}=19)\end{array}$ & p value \\
\hline Tumour size on imaging & $\mathrm{n}=40$ & $\mathrm{n}=19$ & 0.002 \\
\hline$\leq 20 \mathrm{~mm}$ & $28(70 \%)$ & $5(26.32 \%)$ & \\
\hline$>20 \mathrm{~mm}$ & $12(30 \%)$ & $14(73.68 \%)$ & \\
\hline Tumour size on imaging (TNBC) & $\mathrm{n}=16$ & $\mathrm{n}=7$ & $<0.001$ \\
\hline$\leq 20 \mathrm{~mm}$ & $14(87.5 \%)$ & $0(0 \%)$ & \\
\hline$>20 \mathrm{~mm}$ & $2(12.5 \%)$ & $7(100 \%)$ & \\
\hline Lymph node size on imaging & $\mathrm{n}=31$ & $\mathrm{n}=13$ & 0.04 \\
\hline$\leq 15 \mathrm{~mm}$ & $20(64.51 \%)$ & $4(30.77 \%)$ & \\
\hline$>15 \mathrm{~mm}$ & $11(35.49 \%)$ & $9(69.23 \%)$ & \\
\hline Lymph node size on imaging (TNBC) & $\mathrm{n}=12$ & $\mathrm{n}=6$ & 0.737 \\
\hline$\leq 15 \mathrm{~mm}$ & $5(41.67 \%)$ & $3(50 \%)$ & \\
\hline$>15 \mathrm{~mm}$ & $7(58.33 \%)$ & $3(50 \%)$ & \\
\hline $\begin{array}{l}\text { Tumour } \leq 20 \mathrm{~mm} \text { and lymph node } \\
\leq 15 \mathrm{~mm}\end{array}$ & $\mathrm{n}=20$ & $\mathrm{n}=4$ & 0.01 \\
\hline $\begin{array}{l}\text { Number of abnormal lymph nodes on } \\
\text { axillary ultrasound }\end{array}$ & $\mathrm{n}=40$ & $\mathrm{n}=19$ & 0.161 \\
\hline 1 & $38(95 \%)$ & $15(78.95 \%)$ & \\
\hline$>1$ & $2(5 \%)$ & $4(21.05 \%)$ & \\
\hline
\end{tabular}


Table 8: Relation of preoperative imaging results to final lymph node disease burden in patients receiving neoadjuvant therapy - I - Chi square test.

\begin{tabular}{|c|c|c|c|}
\hline Neoadj. & N0-1 $(n=40)$ & $\mathbf{N} 2-3(n=19)$ & p value \\
\hline ER & $\mathrm{n}=40$ & $\mathrm{n}=19$ & 0.361 \\
\hline positive & $16(40 \%)$ & $10(52.63 \%)$ & \\
\hline negative & $24(60 \%)$ & $9(47.37 \%)$ & \\
\hline PR & $\mathrm{n}=40$ & $\mathrm{n}=19$ & 0.432 \\
\hline positive & $7(17.5 \%)$ & $5(26.32 \%)$ & \\
\hline negative & $33(82.5 \%)$ & $14(73.68 \%)$ & \\
\hline Ki67 & $\mathrm{n}=40$ & $\mathrm{n}=19$ & 0.551 \\
\hline positive & $31(77.5 \%)$ & $16(84.22 \%)$ & \\
\hline negative & $9(22.5 \%)$ & $3(15.78 \%)$ & \\
\hline Topoiz. & $\mathrm{n}=40$ & $\mathrm{n}=19$ & 0.305 \\
\hline positive & $24(60 \%)$ & $14(73.68 \%)$ & \\
\hline negative & $16(40 \%)$ & $5(26.32 \%)$ & \\
\hline HER-2 & $\mathrm{n}=40$ & $\mathrm{n}=19$ & 0.323 \\
\hline positive & $11(27.5 \%)$ & $3(15.78 \%)$ & \\
\hline negative & $29(72.5 \%)$ & $16(84.22 \%)$ & \\
\hline Tumour histology on biopsy & $\mathrm{n}=40$ & $\mathrm{n}=19$ & 0.314 \\
\hline Ductal & $29(72.5 \%)$ & $14(73.69 \%)$ & \\
\hline Lobular & $0(0 \%)$ & $1(5.26 \%)$ & \\
\hline Other invasive & $11(27.5 \%)$ & $4(21.05 \%)$ & \\
\hline Histologic grade & $\mathrm{n}=32$ & $\mathrm{n}=18$ & 0.157 \\
\hline $\mathrm{I}$ & $5(15.62 \%)$ & $0(0 \%)$ & \\
\hline II & $12(37.5 \%)$ & $6(33.33 \%)$ & \\
\hline III & $15(46.88 \%)$ & $12(66.67 \%)$ & \\
\hline
\end{tabular}


We examined the likelihood of stage N0-1 in the presence of two preoperative factors: $\leq 20$ $\mathrm{mm}$ tumour size as measured by ultrasound and $\mathrm{a} \leq 15 \mathrm{~mm}$ size of the lymph node considered to be metastatic. In the patient group not receiving neoadjuvant therapy $(\mathrm{p}=0.948)$, this could not be confirmed, but in patients receiving neoadjuvant therapy, the likelihood of maximum 3 metastatic lymph nodes is very high $(\mathrm{p}=0.01)$.

Logistic regression was used to examine which variables are predictive of the axillary status. Using the omnibus test, we found that the independent variables in the model are more related to the dependent variable than we would expect due to chance $(\mathrm{p}<0.001)$. We were able to confirm that the size of the tumour $(\operatorname{Exp}(B)=1.050,95 \% \mathrm{CI}=1.016-1.085, \mathrm{p}=0.004)$ is predictive of the axillary status. The resulting model was statistically significant $(\chi 2=18.806$, $\mathrm{df}=3, \mathrm{p}<0.001)$. Using the model, the proportion of cases categorized correctly was $69.4 \%$ (overall percentage), which leads to a more precise result compared to categorizing by chance $(55.4 \%)$ (Table 9).

Table 9: Results of logistic regression:

\begin{tabular}{lcccc}
\hline Variables & Sig & $\operatorname{Exp}(\mathbf{B})$ & \multicolumn{2}{c}{$\mathbf{9 5 \%}$ CI for $\operatorname{EXP}(\mathbf{B})$} \\
\hline Tumour size & & & Lower & Upper \\
\hline
\end{tabular}

Cases with maximum 2 (Z1) and 3 or more lymph nodes (Z2) were compared with the examinable preoperative factors in patients grouped by receiving or not receiving neoadjuvant therapy.

In patients not receiving neoadjuvant therapy, the size of the breast tumour, the axillary status, clinicopathological characteristics of the tumour showed no correlation with the final histological status of the axilla (Tables 10 and 11). 
Table 10: Relation of preoperative pathological factors to final lymph node disease burden inpatients not receiving neoadjuvant therapy - I - Chi square test.

\begin{tabular}{|c|c|c|c|}
\hline Neoadj. 0 & No-1 $(n=76)$ & $\mathrm{N} 2-3(\mathrm{n}=55)$ & p value \\
\hline Tumour size on imaging & $\mathrm{n}=76$ & $\mathrm{n}=55$ & 0.703 \\
\hline$\leq 20 \mathrm{~mm}$ & $44(57.9 \%)$ & $30(54.5 \%)$ & \\
\hline$>20 \mathrm{~mm}$ & $32(42.1 \%)$ & $25(45.5 \%)$ & \\
\hline Tumour size on imaging (TNBC) & $\mathrm{n}=19$ & $\mathrm{n}=12$ & 0.981 \\
\hline$\leq 20 \mathrm{~mm}$ & $11(57.9 \%)$ & $7(58.3 \%)$ & \\
\hline$>20 \mathrm{~mm}$ & $8(42.1 \%)$ & $5(41.7 \%)$ & \\
\hline Lymph node size on imaging & $n=68$ & $\mathrm{n}=48$ & 0.979 \\
\hline$\leq 15 \mathrm{~mm}$ & $31(45.6 \%)$ & $22(45.8 \%)$ & \\
\hline$>15 \mathrm{~mm}$ & $37(54.4 \%)$ & $26(54.2 \%)$ & \\
\hline Lymph node size on imaging (TNBC) & $\mathrm{n}=17$ & $\mathrm{n}=11$ & 0.453 \\
\hline$\leq 15 \mathrm{~mm}$ & $7(41.17 \%)$ & $3(27.27 \%)$ & \\
\hline$>15 \mathrm{~mm}$ & $10(58.83 \%)$ & $8(72.73 \%)$ & \\
\hline $\begin{array}{l}\text { Tumour } \leq 20 \mathrm{~mm} \text { and lymph node } \\
\leq 15 \mathrm{~mm}\end{array}$ & $\mathrm{n}=31$ & $\mathrm{n}=22$ & 0.948 \\
\hline $\begin{array}{l}\text { Number of abnormal lymph nodes on } \\
\text { axillary ultrasound }\end{array}$ & $\mathrm{n}=76$ & $\mathrm{n}=55$ & 0.338 \\
\hline 1 & $65(85.53 \%)$ & $43(78.18 \%)$ & \\
\hline$>1$ & $11(14.47 \%)$ & $12(21.82 \%)$ & \\
\hline
\end{tabular}


Table 11: Relation of preoperative pathological factors to final lymph node disease burden in patients not receiving neoadjuvant therapy - II - Chi square test.

\begin{tabular}{|c|c|c|c|}
\hline Neoadj. 0 & No-1 $(n=76)$ & $\mathrm{N} 2-3(\mathrm{n}=55)$ & p value \\
\hline ER & $\mathrm{n}=76$ & $\mathrm{n}=55$ & 0.281 \\
\hline positive & $47(61.84 \%)$ & $39(70.91 \%)$ & \\
\hline negative & $29(38.16 \%)$ & $16(29.09 \%)$ & \\
\hline PR & $\mathrm{n}=76$ & $\mathrm{n}=55$ & 0.305 \\
\hline positive & $43(56.58 \%)$ & $36(65.45 \%)$ & \\
\hline negative & $33(43.42 \%)$ & $19(34.55 \%)$ & \\
\hline Ki67 & $\mathrm{n}=76$ & $\mathrm{n}=55$ & 0.845 \\
\hline positive & $64(84.21 \%)$ & $47(85.45 \%)$ & \\
\hline negative & $12(15.79 \%)$ & $8(14.55 \%)$ & \\
\hline Topoiz. & $\mathrm{n}=76$ & $\mathrm{n}=55$ & 0.883 \\
\hline positive & $60(78.95 \%)$ & $44(80 \%)$ & \\
\hline negative & $16(21.05 \%)$ & $11(20 \%)$ & \\
\hline HER-2 & $\mathrm{n}=76$ & $\mathrm{n}=55$ & 0.883 \\
\hline positive & $16(21.05 \%)$ & $11(20 \%)$ & \\
\hline negative & $60(78.95 \%)$ & $44(80 \%)$ & \\
\hline TNBC & $\mathrm{n}=76$ & $\mathrm{n}=55$ & 0.672 \\
\hline yes & $19(25 \%)$ & $12(21.8 \%)$ & \\
\hline no & $57(75 \%)$ & $43(78.2 \%)$ & \\
\hline Tumour histology on biopsy & $\mathrm{n}=76$ & $\mathrm{n}=55$ & 0.871 \\
\hline Ductal & $48(63.16 \%)$ & $33(60 \%)$ & \\
\hline Lobular & $4(5.26 \%)$ & $4(7.27 \%)$ & \\
\hline Other invasive & $24(31.58 \%)$ & $18(32.73 \%)$ & \\
\hline Histologic grade & $\mathrm{n}=65$ & $\mathrm{n}=51$ & 0.576 \\
\hline I & $2(3.08 \%)$ & $3(5.88 \%)$ & \\
\hline II & $27(41.54 \%)$ & $24(47.06 \%)$ & \\
\hline III & $36(55.38 \%)$ & $24(47.06 \%)$ & \\
\hline
\end{tabular}


In patients receiving neoadjuvant therapy, the possibility of maximum 2 metastatic lymph nodes is very high if the size of the tumour is $\leq 20 \mathrm{~mm}(\mathrm{p}=0.008)$ based on the ultrasound examination. The joint presence of two preoperatively examinable factors $-\leq 20 \mathrm{~mm}$ tumour size confirmed by ultrasound and a $\leq 15 \mathrm{~mm}$ size of the lymph node considered to be metastatic - increased the possibility of maximum 2 positive lymph nodes only in patients receiving neoadjuvant therapy $(\mathrm{p}=0.728$ vs. $\mathrm{p}=0.017)($ Table 12$)$.

Table 12: Relation of imaging results to modified final lymph node disease burden (Z1 or Z2) in patients receiving neoadjuvant therapy - I - Chi square test.

\begin{tabular}{|c|c|c|c|}
\hline Neoadj. & Z1 $(n=34)$ & $\mathrm{Z2}(\mathrm{n}=\mathbf{2 5})$ & p value \\
\hline Tumour size on imaging & $\mathrm{n}=34$ & $\mathrm{n}=25$ & 0.008 \\
\hline$\leq 20 \mathrm{~mm}$ & $24(70.58 \%)$ & $9(36 \%)$ & \\
\hline$>20 \mathrm{~mm}$ & $10(29.42 \%)$ & $16(64 \%)$ & \\
\hline Tumour size on imaging (TNBC) & $\mathrm{n}=14$ & $\mathrm{n}=9$ & 0.002 \\
\hline$\leq 20 \mathrm{~mm}$ & $12(85.71 \%)$ & $2(22.22 \%)$ & \\
\hline$>20 \mathrm{~mm}$ & $2(14.29 \%)$ & $7(77.78 \%)$ & \\
\hline Lymph node size on imaging & $\mathrm{n}=28$ & $\mathrm{n}=16$ & 0.086 \\
\hline$\leq 15 \mathrm{~mm}$ & $18(64.29 \%)$ & $6(37.5 \%)$ & \\
\hline$>15 \mathrm{~mm}$ & $10(35.71 \%)$ & $10(62.5 \%)$ & \\
\hline Lymph node size on imaging (TNBC) & $n=11$ & $\mathrm{n}=7$ & 0.914 \\
\hline$\leq 15 \mathrm{~mm}$ & $5(45.45 \%)$ & $3(42.86 \%)$ & \\
\hline$>15 \mathrm{~mm}$ & $6(54.55 \%)$ & $4(57.14 \%)$ & \\
\hline $\begin{array}{l}\text { Tumour } \leq 20 \mathrm{~mm} \text { and lymph node } \\
\leq 15 \mathrm{~mm}\end{array}$ & $\mathrm{n}=18$ & $\mathrm{n}=6$ & 0.017 \\
\hline $\begin{array}{l}\text { Number of abnormal lymph nodes on } \\
\text { axillary ultrasound }\end{array}$ & $\mathrm{n}=34$ & $\mathrm{n}=25$ & 0.177 \\
\hline 1 & $33(97.06 \%)$ & $20(80 \%)$ & \\
\hline$>1$ & $1(2.94 \%)$ & $5(20 \%)$ & \\
\hline
\end{tabular}


The final lymph node status of the axilla showed no connection with other clinicopathological characteristics (Tables 13, 14 and 15).

Table 13: Relation of imaging results to modified final lymph node disease burden (Z1 or Z2) in patients receiving neoadjuvant therapy - II - Chi square test.

\begin{tabular}{|c|c|c|c|}
\hline Neoadj. & Z1 (n=34) & $\mathrm{Z2}(\mathrm{n}=\mathbf{2 5})$ & p value \\
\hline ER & $\mathrm{n}=34$ & $\mathrm{n}=25$ & 0,293 \\
\hline positive & $13(38,24 \%)$ & $13(52 \%)$ & \\
\hline negative & $21(61,76 \%)$ & $12(48 \%)$ & \\
\hline PR & $\mathrm{n}=34$ & $\mathrm{n}=25$ & 0,549 \\
\hline positive & $6(17,65 \%)$ & $6(24 \%)$ & \\
\hline negative & $28(82,35 \%)$ & $19(76 \%)$ & \\
\hline Ki67 & $\mathrm{n}=34$ & $\mathrm{n}=25$ & 0,478 \\
\hline positive & $26(76,47 \%)$ & $21(84 \%)$ & \\
\hline negative & $8(23,53 \%)$ & $4(16 \%)$ & \\
\hline Topoiz. & $\mathrm{n}=34$ & $\mathrm{n}=25$ & 0,111 \\
\hline positive & $19(55,88 \%)$ & $19(76 \%)$ & \\
\hline negative & $15(44,12 \%)$ & $6(24 \%)$ & \\
\hline HER-2 & $\mathrm{n}=34$ & $\mathrm{n}=25$ & 0,967 \\
\hline positive & $8(23,53 \%)$ & $6(24 \%)$ & \\
\hline negative & $26(76,47 \%)$ & $19(76 \%)$ & \\
\hline Tumor histology on biopsy & $\mathrm{n}=34$ & $\mathrm{n}=25$ & 0.446 \\
\hline Ductal & $26(76,47 \%)$ & $17(68 \%)$ & \\
\hline Lobular & $0(0 \%)$ & $1(4 \%)$ & \\
\hline Other invasive & $8(23,53 \%)$ & $7(28 \%)$ & \\
\hline Histologic grade & $\mathrm{n}=28$ & $n=22$ & 0,1 \\
\hline $\mathrm{I}$ & $5(17,86 \%)$ & $0(0 \%)$ & \\
\hline II & $10(35,71 \%)$ & $8(36,36 \%)$ & \\
\hline III & $13(46,43 \%)$ & $14(63,64 \%)$ & \\
\hline
\end{tabular}


Table 14: Relation of imaging results to modified final lymph node disease burden (Z1 or Z2) in patients not receiving neoadjuvant therapy - I - Chi square test.

\begin{tabular}{|c|c|c|c|}
\hline Neoadj. 0 & $\mathrm{Z1}(\mathrm{n}=\mathbf{6 1})$ & $\mathbf{Z 2}(\mathbf{n}=\mathbf{7 0})$ & p value \\
\hline Tumor size on imaging & $\mathrm{n}=61$ & $\mathrm{n}=70$ & 0,369 \\
\hline$\leq 20 \mathrm{~mm}$ & $\begin{array}{c}37 \\
(60,65 \%)\end{array}$ & $\begin{array}{c}37 \\
(52,86 \%)\end{array}$ & \\
\hline$>20 \mathrm{~mm}$ & $\begin{array}{c}24 \\
(39,35 \%)\end{array}$ & $\begin{array}{c}33 \\
(47,14 \%)\end{array}$ & \\
\hline Tumour size on imaging (TNBC) & $\mathrm{n}=17$ & $\mathrm{n}=14$ & 0,323 \\
\hline$\leq 20 \mathrm{~mm}$ & $11(64,7 \%)$ & $7(50 \%)$ & \\
\hline$>20 \mathrm{~mm}$ & $6(35,3 \%)$ & $7(50 \%)$ & \\
\hline Lymph node size on imaging & $\mathrm{n}=53$ & $\mathrm{n}=63$ & 0,936 \\
\hline$\leq 15 \mathrm{~mm}$ & $\begin{array}{c}24 \\
(45,28 \%)\end{array}$ & $29(46 \%)$ & \\
\hline$>15 \mathrm{~mm}$ & $\begin{array}{c}29 \\
(54,72 \%)\end{array}$ & $34(54 \%)$ & \\
\hline Lymph node size on imaging (TNBC) & $\mathrm{n}=15$ & $\mathrm{n}=13$ & 0,184 \\
\hline$\leq 15 \mathrm{~mm}$ & $7(46,67 \%)$ & $3(23,07 \%)$ & \\
\hline$>15 \mathrm{~mm}$ & $8(53,33 \%)$ & $\begin{array}{c}10 \\
(76,93 \%)\end{array}$ & \\
\hline $\begin{array}{l}\text { Tumor }<20 \mathrm{~mm} \& \text { Lymph node } \\
<15 \mathrm{~mm}\end{array}$ & $\mathrm{n}=24$ & $\mathrm{n}=29$ & 0,728 \\
\hline $\begin{array}{l}\text { Number of abnormal lymph nodes on } \\
\text { axillary ultrasound }\end{array}$ & $\mathrm{n}=61$ & $\mathrm{n}=70$ & 0,083 \\
\hline 1 & $\begin{array}{c}55 \\
(90,16 \%)\end{array}$ & $\begin{array}{c}53 \\
(75,71 \%) \\
\end{array}$ & \\
\hline$>1$ & $6(9,84 \%)$ & $\begin{array}{c}17 \\
(24,29 \%)\end{array}$ & \\
\hline
\end{tabular}


Table 15: Relation of imaging results to modified final lymph node disease burden (Z1 or Z2) in patients not receiving neoadjuvant therapy - II - Chi square test.

\begin{tabular}{|c|c|c|c|}
\hline Neoadj. 0 & $\mathrm{Z1}(\mathrm{n}=61)$ & $\mathrm{Z2}(\mathrm{n}=70)$ & p value \\
\hline ER & $\mathrm{n}=61$ & $\mathrm{n}=70$ & 0,451 \\
\hline positive & $38(62,30 \%)$ & $48(68,57 \%)$ & \\
\hline negative & $23(37,70 \%)$ & $22(31,43 \%)$ & \\
\hline PR & $\mathrm{n}=61$ & $\mathrm{n}=70$ & 0,319 \\
\hline positive & $34(55,74 \%)$ & $45(64,29 \%)$ & \\
\hline negative & $27(44,26 \%)$ & $25(35,71 \%)$ & \\
\hline Ki67 & $\mathrm{n}=61$ & $\mathrm{n}=70$ & 0,879 \\
\hline positive & $52(85,25 \%)$ & $59(84,29 \%)$ & \\
\hline negative & $9(14,75 \%)$ & $11(15,71 \%)$ & \\
\hline Topoiz. & $\mathrm{n}=61$ & $\mathrm{n}=70$ & 0,853 \\
\hline positive & $48(78,69 \%)$ & $56(80 \%)$ & \\
\hline negative & $13(21,31 \%)$ & $14(20 \%)$ & \\
\hline HER-2 & $\mathrm{n}=61$ & $\mathrm{n}=70$ & 0,122 \\
\hline positive & $9(14,75 \%)$ & $18(25,71 \%)$ & \\
\hline negative & $52(85,25 \%)$ & $52(74,29 \%)$ & \\
\hline TNBC & $n=61$ & $\mathrm{n}=70$ & 0,197 \\
\hline yes & $17(27,87 \%)$ & $14(20 \%)$ & \\
\hline no & $44(72,13 \%)$ & $56(80 \%)$ & \\
\hline Tumor histology on biopsy & $\mathrm{n}=61$ & $\mathrm{n}=70$ & 0,826 \\
\hline Ductal & $36(59,02 \%)$ & $45(64,29 \%)$ & \\
\hline Lobular & $4(6,55 \%)$ & $4(5,71 \%)$ & \\
\hline Other invasive & $21(34,43 \%)$ & $21(30 \%)$ & \\
\hline Histologic grade & $\mathrm{n}=51$ & $\mathrm{n}=65$ & 0,396 \\
\hline $\mathrm{I}$ & $2(3,92 \%)$ & $3(4,62 \%)$ & \\
\hline II & $19(37,255 \%)$ & $32(49,23 \%)$ & \\
\hline III & $30(58,825 \%)$ & $30(46,15 \%)$ & \\
\hline
\end{tabular}




\section{DISCUSSION}

In the past 100 years we have seen an enormous development in the surgical treatment of breast cancer, and this is especially true for axillary surgery. The previously mandatory axillary block dissection, the removal of stage 1 or stage 2 axillary lymph nodes has been replaced by sentinel lymph node biopsy, and the indications for ABD have become considerably limited.

Besides local tumour control, the fundamental aim of axillary surgery is to obtain accurate information about the involvement of the axilla in cancer, which is crucially important in the future therapy and prognosis of the cancer.

The spreading of cancer along lymphatic vessels and the effect of this spreading on treatment and survival has been studied for centuries. Theories on the dissemination of solid tumours are based on experimental data and observations. These results have generated numerous debates on the legitimacy of regional lymph node dissection, and on whether the disease is the initially systemic or locoregional in nature. Complete regional lymph node dissection proved to be controversial, since this procedure is considered overtreatment in patients without lymph node metastases. These cases are characterised by an increased number of postoperative complications without an improvement in survival. The introduction of sentinel lymph node biopsy offered a less invasive procedure for the detection of lymph node metastases. ${ }^{1,2}$

Bartholin was the first to discover lymphatic dissemination in 1653. Several studies afterwards confirmed the complexity of the lymphatic system. In the 19th century, Virchow formulated his theory claiming that lymph nodes filter certain particles from the blood. This important discovery led to the assumption that cancer at an early stage could be treated by the appropriate surgical intervention. The next step in the development of Virchow's hypothesis was the introduction of Halsted radical mastectomy at the end of the 19th century. To determine the barrier function of lymph nodes, researchers injected inanimate particles or tumour cells into certain afferent lymphatic vessels in animal studies. Studying the mesentery of different animals, Gilchrist observed that injected carbon suspensions did not pass through certain lymph nodes. Zeidman and Buss injected carcinoma cells into popliteal afferent lymphatic vessels in rabbits. They observed that tumour cell emboli are immediately captured in subcapsular sinuses and are unable to spread to the next lymph node for at least 3 weeks. ${ }^{33}$

The first theory - also referred to as locoregional theory - was developed by Halsted. Essentially, this theory claims that the cancer appears locally at first, and the tumour cells then spread to regional lymph nodes directly by a process called permeation. Thus, the tumour first invades the 
breast structures, then metastasizes first in regional lymph nodes, which serve as barriers for the rest of the body with their filtering function. Therefore, in addition to the removal of the primary tumour, if these lymph nodes also show tumour lesions, they must also be removed. This theory is reflected in Halsted's radical, or even ultra-radical mastectomy, which involves the removal of the entire breast and also the chest muscle, regional lymph nodes, and even the parasternal lymph nodes.

The systemic hypothesis of breast cancer was suggested by Bernard Fisher. In his view, there is no preconceived course of the spread of tumour cells. The tumour cells first enter lymphatic vessels through a process called embolization, where lymphatic circulation carries them to regional lymph nodes. This theory suggests that regional lymph nodes are not always involved in the malignancy and their involvement is not necessarily the source of a systemic disease - this is rather an indicator. The theory attaches great significance to hematogenous dissemination already at an early stage of the disease.

Hellman's theory, the currently most widely accepted theory, which is based on these two theories, states that the tumour first appears locally and then disseminates via regional lymph nodes into regional and finally distant organs to become a systemic disease. ${ }^{35}$

In light of the above, it is remarkable that the concept of lymphatic mapping was not described until the end of the 20th century. Morton and co-workers have used lymphoscintigraphy with colloidal gold since 1977 to map the lymphatic drainage pattern of melanomas. Besides this preoperative procedure, they also developed an intraoperative technique to remove lymph nodes along the direct drainage pathway of the primary melanoma. They considered this sentinel lymph node to be the primary site of metastasis.

The procedure of sentinel lymph node biopsy was introduced into clinical practice in the 1990s. The procedure is based on two basic principles: the existence of an orderly lymphatic drainage pattern to regional lymph nodes, and the sentinel lymph node is the first stop tumour cells reach on their dissemination journey originating from the primary tumour. This concept is based on the theory of Halsted with a large contribution by the experimental work of Gilchrist and Zeidman, which provided support for dissemination through the lymphatic system. 1989 marks the general acceptance and widespread use of the procedure. ${ }^{33}$

The introduction of sentinel lymph node biopsy in patients with breast cancer was initiated in 1991. Blue dye mapping of lymphatic drainage in breast cancer was first performed by Guiliano . ${ }^{1,2}$ Administration of radiolabelled colloids for intraoperative detection of the sentinel lymph 
node using a gamma-ray detection probe was introduced later. ${ }^{3}$ Preoperative lymphoscintigraphy enabled the accurate determination of the location and number of sentinel lymph nodes. Different methods based on these two techniques are now applied all around the world. ${ }^{33}$ Its significance lies in the fact that it considerably reduced the development of lymphoedema - the infamous side effect of axillary procedures - compared to block dissection. ${ }^{34,36}$

In addition to sentinel lymph node biopsy, preoperative ultrasound and aspiration cytology sampling are the most commonly used and studied examinations used for the detection of axillary metastases in newly diagnosed breast cancer.

Axillary ultrasound was first used in combination with aspiration cytology sampling for the diagnosis of axillary lymph nodes suspected of containing metastases in 1997. Aspiration cytology is more commonly used, as it is quick, less painful for the patient, and also cost effective. Its disadvantage is that a negative finding does not rule out malignancy, but a positive finding is considered valid.

\section{a) Is intraoperative touch imprint cytology indicated in the surgical treatment of early breast cancers?}

In the meantime, intraoperative processing of sentinel lymph nodes became increasingly widespread, as its use helped avoid surgery in two sittings thereby reducing patient burden and surgery costs. ${ }^{1,3}$

Intraoperative histological examinations include imprint cytology, frozen section histology and a nucleic acid amplification study. The specificity and sensitivity of these examinations are similar. The sensitivity of the nucleic acid amplification study is $76.9-98.2 \%$, and that of frozen section histology and imprint cytology varies between 68.49 and $98.81 \%$. The specificity of all three methods is considered almost $100 \% ., 4,5,6$

Studies and guidelines published in the past 10 years (ACOSOG Z0011, NCCN Guidelines, St. Gallen Consensus Conference, German-Austrian-Swiss Consensus Conference, IBCSG 23-01) in cases that are in compliance with certain criteria (including isolated tumour cells, micrometastasis and in cases of a sentinel lymph node containing no more than two macrometastases, the patient undergoes breast-conserving surgery and receives systemic oncological treatment and whole-breast irradiation), consider axillary block dissection avoidable, as this does not pose a risk in terms of overall survival or local recurrence. ${ }^{8,9,13,14,15}$ Similarly, the indication of $\mathrm{ABD}$ is reduced by clinical studies supporting the fact that axillary radiation is an 
alternative treatment option to surgery, but it is associated with lower morbidity (as in the OTOASOR and AMAROS trials) ${ }^{11,12,17}$ Axillary radiotherapy does not pose an increased risk to survival and locally recurring cancer, and the incidence of lymphedema that is primarily responsible for morbidity is significantly decreased as well. According to the AMAROS study, lymphedema occurred in $23 \%$ of the cases five years after axillary block dissection, while this was $11 \%$ in patients treated with axillary radiation. ${ }^{12}$ Another important factor is that in the case of axillary block dissection performed for positive imprint cytology, the patient is unable to participate in the therapeutic decision and choose from among therapeutic options.

These factors suggest a reconsideration of the routine use of imprint cytology. Based on our results, the sensitivity of imprint cytology is $57.18 \%$, its specificity is $99.63 \%$, and these values are consistent with international data. (The sensitivity of imprint cytology varies between 68.49 and $98.81 \%$, with a specificity of approximately $100 \%) .^{5,37,38,39}$ With regard to metastasis sizes and distribution, imprint cytology is less suited to detecting metastases of $2 \mathrm{~mm}$ or smaller, with $84.15 \%$ of micrometastases remaining undetected, but $70.3 \%$ of macrometastases can be detected with this method.

However, according to the latest guidelines, the sensitivity of imprint cytology (based on cases with therapeutic consequences) is only $34.23 \%$ (with unchanged specificity). This sensitivity value is so low that the usability of this method is questionable. ABD was only indicated in $9 \%$ of the patients in the period under examination (105/1168). However, based on the new guidelines, supplementary lymph node dissection was performed "unnecessarily" in $15.32 \%$ of the patients (179/1168). It is not insignificant that imprint cytology increased surgical costs and the duration of surgery unnecessarily in a large percentage of the patients $(91 \%)$.

First study shows that axillary block dissection is only necessary in the treatment of the axillary region in an increasingly smaller group of patients (9\%), and this percentage will further decrease with more extensive use of alternative axillary radiotherapy.

Based on our results, imprint cytology of the sentinel lymph node(s) in patients operated on for malignant breast cancer has no confirmed benefits based on the current guidelines, and its routine use is not indicated. According to the latest international guidelines, intraoperative examination of the sentinel lymph node(s) may be indicated in the case of mastectomy (when postoperative radiotherapy is not planned) and after neoadjuvant therapy, as ABD is still indicated in these cases. 


\section{b) Is axillary lymph node dissection necessary for positive preoperative aspiration cytology lymph node results?}

Nowadays, the effort to further limit the indication area of ALND accompanied by significant morbidity is completely reasonable. One way to do this is to preoperatively screen patients only at N1 stage axillary status. Based on several international guidelines (National Comprehensive Cancer Network [NCCN], St. Gallen consensus conference, ESO-ESMO international consensus conference, Hungarian Breast Cancer Consensus Conference), in cases characterised by the presence of axillary lymph nodes considered to be negative by preoperative examinations, sentinel lymph node biopsy should be performed, and with axillary lymph nodes considered to be positive, aspiration cytology or core biopsy should be performed. ${ }^{31,40,41,42}$ Several research groups have studied which factors detected or examined during the preoperative period (imaging studies, histological finding, immunohistochemistry status, location of the tumour etc.) may be suitable to determine whether sentinel lymph node biopsy (SLNB) or axillary lymph node dissection (ALND) should be performed during the surgery with certainty even before the surgery in cases with positive axillary ultrasound and positive aspiration cytology. ${ }^{26,43,44}$ In the post-Z0011 period of the treatment of breast tumours, not only the presence of an axillary metastasis is examined, but positive cases are also differentiated as mild (N1 lymph node status, 1 to 3 positive lymph nodes) and severe (N2 lymph node status, 4 or more positive lymph nodes) axillary metastases. Lim et al. have confirmed that if the patient meets the criteria of the Z0011 study, and the axillary ultrasound detects 3 or more positive lymph nodes, it is very likely that there are multiple positive lymph nodes in the axilla; therefore, axillary lymph node dissection cannot be avoided. ${ }^{43}$ This result has also been confirmed by the study of Liu et al., which found that ALND may be avoided if patients meet the criteria of the Z0011 study, and the axillary ultrasound examination confirms only one suspected metastatic lymph node. If - based on ultrasound examination - two lymph nodes are considered to be metastatic, histological sampling and axillary lymph node dissection are recommended (the latter subject to positive histology findings). ${ }^{45}$ The study of Liang et al. highlights the importance of preoperative histological examination; the authors have shown that in cases where axillary lymph nodes are found to be positive with fine needle aspiration cytology, the patient is more likely to have more than 3 metastatic lymph nodes in the axilla, compared to cases where the sentinel lymph node biopsy confirms 1 to 2 metastatic lymph nodes. $^{46}$

In our study, we examined which combination of preoperative parameters would allow axillary lymph node dissection to be avoided, if axillary lymph node involvement is confirmed 
preoperatively. Data of 2671 cases were analysed: axillary ultrasound was performed in all cases, a metastatic lymph node was found in 260 cases, from which aspiration cytology was also performed. The examination confirmed metastasis in 190 cases. In these cases, based on the guidelines of previous consensus conferences, axillary lymph node dissection was performed as the primary surgery both in patients receiving neoadjuvant therapy and in patients not receiving neoadjuvant therapy. ${ }^{31,40} \mathrm{We}$ also examined which of these clinicopathological characteristics could eliminate the need for this radical surgical intervention. Based on our results, the severity of the involvement of the axillary region in the tumour process could not be clearly predicted preoperatively with the clinicopatholgical characteristics of the tumour in patients not receiving neoadjuvant therapy (N0-1 vs. N2-3). In contrast, a study conducted in the United States of America and published in 2017 confirmed that primary ALND is not necessary and SLNB is recommended if the preoperative breast ultrasound confirmed a 2-cm or smaller primary tumour in the breast, maximum one positive lymph node is confirmed with aspiration cytology, and the patient does not receive neoadjuvant therapy. ${ }^{26}$ In their retrospective study conducted in the United Kingdom, Lloyd et al. also found that patients are very likely to have maximum 2 or less axillary lymph nodes with macrometastasis if the preoperative ultrasound confirmed a $20-\mathrm{mm}$ or smaller primary tumour, histology of this tumour confirmed invasive ductal or lobular carcinoma, and breast conserving surgery was performed. Therefore, in these cases, ALND represents overtreatment. $^{44}$ Differences between our study findings and international literature are presumably due to the differences observed in the clinicopathological characteristics of the tumours.

Based on our study we claim that N0-1 lymph node status in patients not receiving neoadjuvant therapy cannot be safely determined by preoperative examinations, while the lymph node status of patients receiving neoadjuvant chemotherapy can be predicted with great certainty based on the results of the preoperative ultrasound examination. If the patients also receive neoadjuvant therapy, it can be predicted with high probability whether the disease is in stage N0-1 or not, and whether axillary lymph node dissection can be avoided or not based on the preoperative size of the tumour $(\leq 20 \mathrm{~mm}, \mathrm{p}=0.002)$ and the preoperative size of the lymph node $(\leq 15 \mathrm{~mm}, \mathrm{p}=$ $0.04)$.

In patients with breast tumours, lymph node status of the axilla has a key role in planning the local and systemic therapy. If there is a metastatic lymph node in the axilla, a significant proportion of patients receive neoadjuvant systemic therapy, which resolves the axillary metastatic process in approximately $40 \%$ of the cases. ${ }^{47}$ Following neoadjuvant therapy, the 
standard surgical procedure in these patients was axillary lymph node dissection even in cases with complete pathological remission. Several studies have addressed the question of sentinel lymph node biopsy and repeated biopsy after neoadjuvant therapy (for example: SENTINA). ${ }^{48}$ In the ACOSOG Z1071 study, the rate of false negative sentinel lymph node biopsies was close to $10 \%$ false negative (12.6\%), and this value further decreased with the removal of the lymph node indicated with a marker (metal clip) during axillary core biopsy. During the surgical intervention, the sentinel lymph node is already detected using the classical dual tracer method (technetium 99m-labelled human colloidal albumin and blue dye). With this technique (targeted axillary dissection, TAD) the rate of false negative sentinel lymph nodes decreased to approximately $2 \%$ 49,50,51,52 Pilewski et al. analysed data from 425 patients and studied to what extent preoperative imaging studies influence the lymph node status of the axilla. If the examinations suggested the presence of a metastatic lymph node, and the patient met the criteria of the Z0011 study, axillary lymph node dissection could have been avoided in $71 \%$ of the cases. If aspiration cytology was positive, ALND was unnecessary in $45 \% .53,54$ Our analyses confirmed the same result. Following neoadjuvant therapy, maximum 3, and maximum 2 positive lymph nodes were confirmed with the final histology in two-thirds $(40 / 59,68 \%)$, and in over $50 \%(34 / 59,57 \%)$ of the cases, respectively; therefore, axillary lymph node dissection could have been avoided. A Spanish study published in 2018 also investigated whether axillary lymph node dissection should be performed after neoadjuvant therapy in cases where an axillary lymph node is considered to be positive with aspiration cytology. In cases showing a significant presence of the Her2 receptor and low expression of the oestrogen receptor, there is a high chance that complete pathological remission occurs, and in these cases, ALND was not recommended. ${ }^{47}$

In a meta-analysis published in 2016, data from 3398 patients were reviewed, and the authors aimed to see whether axillary lymph node dissection is necessary after neoadjuvant therapy in lymph node positive breast tumour cases. According to the analysis, the recommended treatment strategy at present is axillary lymph node dissection. However, optimizing preoperative examinations and screening the patient population may help to achieve a more precise preoperative evaluation of the axillary lymph node status. In the future, performing SLN with dual tracer method, labelling the positive axillary lymph node in advance with a metal clip or with a radiopharmaceutical containing iodine, followed by the removal of the labelled lymph node may decrease the number of axillary lymph node dissections. Based on the analysis, HER2 positive and triple negative cases by immunochemistry require further studies. ${ }^{23} \mathrm{~A}$ study published in 2017 showed that the efficacy of neoadjuvant therapy did not differ in these cases, 
but further studies are recommended in these cases as well. ${ }^{24}$ Our study also showed, in patients with triple negative breast cancer (TNBC) who receive neoadjuvant therapy, if the size of the tumour is $\leq 20 \mathrm{~mm}$, the axillary lymph node status is N0-1 in $87.5 \%$ of the patients. The same result was found in a study performed in 2016; ALND could be avoided after neoadjuvant therapy in $48 \%$ of the patients, especially in case of HER 2 receptor positive and triple receptor negative cases. The study supported performing sentinel lymph node biopsy in patients with breast tumour receiving neoadjuvant therapy and with multiple axillary lymph node metastases as well. To support the results, longer studies are required. ${ }^{25}$ The retrospective study of Pilewski, which processed data from 1944 patients confirms this result; the study concluded that if patients receive neoadjuvant therapy followed by mastectomy, and the receptor status is HER2 positive and triple receptor negative, ALND could most likely have been avoided. ${ }^{55}$ Low oestrogen, and increased Her2 receptor and Ki67 expression results in higher numbers of pathological regression. Axillary block dissection is not recommended in these cases. ${ }^{47}$

In an ideal situation, preoperative axillary examination not only identifies the positive lymph nodes, but also helps in selecting the proper treatment plan, and as a result, patients may receive individualized medical care. In accordance with our results, detecting the suspicious lymph nodes with axillary ultrasound examination may predict the stage of the disease; therefore, we consider the complete examination of the axilla important in excluding potential lymph node metastases. With patients under check-up examinations due to an invasive breast tumour, the preoperative size of the tumour, the size of the lymph node in case of positive aspiration cytology can be used to identify patients with stage N0-1 lymph nodes. Our results confirm that in patients receiving neoadjuvant therapy, in addition to the preoperative size of the tumour $(\leq 20 \mathrm{~mm}, \mathrm{p}=0.002)$, the preoperative size of the lymph node $(\leq 15 \mathrm{~mm}, \mathrm{p}=0.04)$ may also be used to predict that the stage of the disease is N0-1. In neoadjuvant therapy, labelling the suspectedly positive lymph nodes - with metal clips, for example - followed by the surgical removal of the affected lymph node, then the administration of adjuvant, targeted radiotherapy and close follow-up may be adequate treatment for the patient. ${ }^{49,50,56}$ 


\section{CONCLUSIONS:}

1) Our findings indicate that imprint cytology assessment of sentinel lymph nodes offers no justifiable benefit in the context of current guidelines; thus, its routine use is no longer reasonable in the surgical treatment of early breast cancer. Based on the latest international guidelines, intraoperative assessment of sentinel lymph nodes is indicated in mastectomy (when no postoperative irradiation is planned) and after neoadjuvant therapy, as in these cases, ABD is still recommended.

2) In cases with positive preoperative axillary ultrasound and aspiration cytology, if the breast tumour is $\leq 20 \mathrm{~mm}$, and the patient receives neoadjuvant therapy, the axilla is most probably in stage N0-1. In these cases, marking the positive lymph node, and removal of this involved lymph node during surgery, as well as targeted adjuvant radiotherapy and close monitoring is an adequate treatment alternative to ABD. 


\section{ACKNOWLEDGEMENTS}

I want to express my gratitude to Dr György Lázár university professor, who oversaw my work as supervisor. I am grateful for his valuable professional advice that he gave me over the past years and that contributed significantly to the success of my scientific activity. I also wish to thank him for his invaluable help in preparing my scientific publications and also for his meticulous and comprehensive review of my thesis.

I thank my breast surgeon colleagues Dr Attila Paszt and Dr Zsolt Simonka for their feedback they provided during informal discussions, which contributed to shaping my attitude.

I would like to express my gratitude for the staff members of the breast tumor board: Professor Judit Olah, Professor Zsuzsanna Kahán, Katalin Ormándi, Csilla Hoffmann, Anna Telek, Gabriella Uhercsák, Alíz Nikolényi, Erzsébet Valicsek, Dóra Sántha, Melinda Csenki, Ágnes Dobi, Gyöngyi Kelemen, Renáta Lilla Kószó, Professor Gábor Cserni, Sándor Hamar, László Kaizer, András Vörös, Tamás Zombori, Orsolya Oláh-Németh, Sándor Turkevi-Nagy, Alex Jenei, Anita Sejben, Tamás Pancsa. Their high quality work helped this dissertation to come into existence.

I express special thanks to the breast histopathology team whose work was essential for the publications appearance: Sándor Hamar, László Kaizer, András Vörös, Erika Csörgő.

I also thank all my colleagues at the Department of Surgery, of the Faculty of Medicine, University of Szeged for helping me to the best of their abilities.

I am grateful to my friends for their understanding and help. Last but not least, I am thankful to my family for their unwavering support. To my parents for guiding me in life and towards scientific research. To my wife, Dr Melinda Látos who is always there providing love and professional support, and my son, Ádám, who always recharges me. 


\section{REFERENCES}

1. Giuliano AE, Kirgan DM, Guenther JM, et al. Lymphatic mapping and sentinel lymphadenectomy for breast cancer. Ann Surg 1994;220:391-401.

2. Giuliano AE, Dale PS, Turner RR, et al. Improved axillary staging of breast cancer with sentinel lymphadenectomy. Ann Surg 1995;222:394-401.

3. Krag DN, Weaver DL, Alex JC, Fairbank JT. Surgical resection and radiolocalization of the sentinel lymphnode in breastcance rusing a gamma probe. Surg Oncol 1993;2(6):335-40.

4. Le Frère-Belda MA, Bats AS, Gillaizeau F, et al. Diagnostic performance of one-step nucleic acid amplification for intraoperative sentinel node metastasis detection in breast cancer patients. Int J Cancer 2012;130(10):2377-86.

5. Safai A, Razeghi A, Monabati A, Azarpira N, Talei A. Comparing touch imprint cytology, frozensection analysis, and cytokeratin immunostaining for intraoperative evaluation of axillary sentinel lymphnodes in breastcancer. Indian J PatholMicrobiol 2012;55(2):183-6.

6. Cserni G. Intraoperative analysis of sentinel lymph nodes in breast cancer by one-step nucleic acid amplification. J Clin Pathol 2012;65:193-9.

7. Pathmanathan N, Renthawa J, French JR, et al. Intraoperative sentinel lymph node assessment in breast cancer: a comparison of rapid diagnostic method based on CK19 mRNA expression and imprint cytology. ANZ J Surg 2014;84(10):730-4.

8. Giuliano AE, McCall L, Beitsch P, et al. Locoregional recurrence after sentinel lymphnode dissection with or withou taxillary dissection in patients with sentinel lymphnode metastases: the American College of Surgeons Oncology Group Z0011 randomized trial. Ann Surg 2010;252(3):426-32.

9. Galimberti V, Cole BF, Viale G, Veronesi P, Vicini E, Intra M, Mazzarol G, Massarut S, Zgajnar J, Taffurelli M, Littlejohn D, Knauer M, Tondini C, Di Leo A, Colleoni M, Regan MM, Coates AS, Gelber RD, Goldhirsch A; International Breast Cancer Study Group Trial 23-01. Axillarydissection versus no axillary dissection in patients with sentinel-node micrometastases (IBCSG 23-01): aphase 3 randomised controlled trial. Lancet Oncol 2013;14:297-305.

10. Solá M, Alberro JA, Fraile M, et al. Complete axillary lymph node dissection versus clinical follow-up in breast cancer patients with sentinel node micrometastasis: final results from the multicenter clinical trial AATRM 048/13/2000. Ann. Surg Oncol 2013;20: 120-7.

11. Rutgers EJ, Donker M, Straver ME, et al. Radiotherapy or surgery of the axilla after a positive sentinel node in breast cancer patients: Final analysis of the EORTC AMAROS trial (10981/22023). J Clin Oncol 2013;31(Suppl.):abstr LBA 1001.

12. Donker M, van Tienhoven G, Straver ME, Meijnen P, van de Velde CJ, Mansel RE, Cataliotti L, Westenberg AH, Klinkenbijl JH, Orzalesi L, Bouma WH, van der Mijle HC, Nieuwenhuijzen GA, Veltkamp SC, Slaets L, Duez NJ, de Graaf PW, van Dalen T, Marinelli A, Rijna H, Snoj M, Bundred NJ, Merkus JW, Belkacemi Y, Petignat P, Schinagl DA, Coens C, Messina CG, Bogaerts J, Rutgers EJ. Radiotherapy or surgery of the axilla after a positive sentinel node in breast cancer (EORTC 10981-22023 AMAROS): a randomised, multicentre, open-label, phase 3 non-inferiority trial. Lancet Oncol. Nov; 2014 15(12):1303-1310.

13. Goldhirsch A, Wood WC, Coates AS. et al. Strategies for subtypes - dealing with the diversity of breast cancer: highlights of the St. Gallen International Expert Consensus on the Primary Therapy of Early Breast Cancer 2011. Ann Oncol 2011;22(8):1736-47. 
14. AGO; DGS; SGS; ÖGS; Panelists; Executive Board Members. German, Austrian and Swiss consensus conference on the diagnosis and local treatment of the axilla in breast cancer. Eur $J$ Cancer. 2013;49(10):2277-83.

15. Goldhirsch A, Winer EP, Coates AS, et al. Personalizing the treatment of women with early breast cancer: highlights of the St Gallen International Expert Consensus on the Primary Therapy of Early Breast Cancer 2013. Ann. Oncol 2013;24:2206-23.

16. National Comprehensive Cancer Network: Clinical practice guidelines in oncology - Breast cancer Version1. 2016. [cited 2015 Nov 18]. Available from:

http://www.nccn.org/professionals/physician_gls/pdf/breast.pdf

17. Sávolt A, Polgár Cs, Musonda P, et al. Does the result of completion axillary lymph node dissection influence the recommendation for adjuvant treatment in sentinel lymph node-positive patients? Clin Breast Cancer 2013;13:364-70.

18. Helfgott, Mittlböck, Miesbauer, Moinfar, Haim, Mascherbauer, Schlagnitweit, Heck, Knauer, Fitzal. The influence of breast cancer subtypes on axillary ultrasound accuracy: A retrospective single center analysis of 583 women. Eur J Surg Oncol. 2018 Oct 10.

19. Topps AR, Barr SP, Pikoulas P, Pritchard SA, Maxwell AJ. Pre-operative Axillary UltrasoundGuided Needle Sampling in Breast Cancer: Comparing the Sensitivity of Fine Needle Aspiration Cytology and Core Needle Biopsy. Ann Surg Oncol. 2018 Jan;25(1):148-153.

20. Vidya R, Iqbal FM, Bickley B. Pre-operative axillary staging: should core biopsy be preferred to fine needle aspiration cytology? Ecancermedicalscience. 2017 Mar 7;11:724.

21. Vijayaraghavan GR, Vedantham S, Kataoka M, DeBenedectis C, Quinlan RM. The Relevance of Ultrasound Imaging of Suspicious Axillary Lymph Nodes and Fine-needle Aspiration Biopsy in the Post-ACOSOG Z11 Era in Early Breast Cancer. Acad Radiol. 2017 Mar;24(3):308-315.

22. Zhu Y, Zhou W, Zhou JQ, Fei XC, Ye TJ, Huang O, Chen XS, Zhan WW. Axillary Staging of Early-Stage Invasive Breast Cancer by Ultrasound-Guided Fine-Needle Aspiration Cytology: Which Ultrasound Criteria for Classifying Abnormal Lymph Nodes Should Be Adopted in the Post-ACOSOG Z0011 Trial Era? J Ultrasound Med. 2016 May;35(5):885-93.

23. El Hage Chehade H, Headon H, El Tokhy O, Heeney J, Kasem A, Mokbel K. Is sentinel lymph node biopsy a viable alternative to complete axillary dissection following neoadjuvant chemotherapy in women with node-positive breast cancer at diagnosis? An updated metaanalysis involving 3,398 patients. Am J Surg. 2016 Nov;212(5):969-981.

24. Tadros AB, Yang WT, Krishnamurthy S, Rauch GM, Smith BD, Valero V, Black DM, Lucci A Jr, Caudle AS, DeSnyder SM, Teshome M, Barcenas CH, Miggins M, Adrada BE, Moseley T, Hwang RF, Hunt KK, Kuerer HM. Identification of Patients With Documented Pathologic Complete Response in the Breast After Neoadjuvant Chemotherapy for Omission of Axillary Surgery. JAMA Surg. 2017 Jul 1;152(7):665-670.

25. Mamtani A, Barrio AV, King TA, Van Zee KJ, Plitas G, Pilewskie M, El-Tamer M, Gemignani ML, Heerdt AS, Sclafani LM, Sacchini V, Cody HS 3rd, Patil S, Morrow M. How Often Does Neoadjuvant Chemotherapy Avoid Axillary Dissection in Patients With Histologically Confirmed Nodal Metastases? Results of a Prospective Study. Ann Surg Oncol. 2016 Oct;23(11):3467-3474.

26. Harris CK, Tran HT, Lee K, Mylander C, Pack D, Rosman M, Tafra L, Umbricht CB, Andrade R, Liang W, Jackson RS. Positive Ultrasound-guided Lymph Node Needle Biopsy in Breast Cancer may not Mandate Axillary Lymph Node Dissection. Ann Surg Oncol. 2017 Oct;24(10):3004-3010 
27. Guenther JM, Hansen NM, DiFronzo LA, Giuliano AE, Collins JC, Grube BL, et al. Axillary dissection is not required for all patients with breast cancer and positive sentinel nodes. Arch Surg 2003;138:52-6

28. Jeruss JS, Winchester DJ, Sener SF, Brinkmann EM, Bilimoria MM, Barrera E Jr, et al. Axillary recurrence after sentinel node biopsy. Ann Surg Oncol 2005;12:34-40.

29. A.E. Giuliano, K.K. Hunt, K.V. Ballman, P.D. Beitsch, P.W. Whitworth, P.W. Blumencranz, et al. Axillary dissection vs no axillary dissection in women with invasive breast cancer and sentinel node metastasis: a randomized clinical trial JAMA, 305 (2011), pp. 569-575

30. A.E. Giuliano, K.V. Ballman, L. McCall, P.D. Beitsch, M.B. Brennan, P.R. Kelemen, et al. Effect of axillary dissection vs No axillary dissection on 10-year overall survival among women with invasive breast cancer and sentinel node metastasis: the ACOSOG Z0011 (Alliance) randomized clinical trial JAMA, 318 (2017), pp. 918-926

31. Lázár G, Bursics A, Farsang Z, Harsányi L, Kósa C, Maráz R, Mátrai Z, Paszt A, Pavlovics G, Tamás R. [3rd Hungarian Breast Cancer Consensus Conference - Surgery Guidelines]. Magy Onkol. 2016 Sep;60(3):194-207.

32. Albertini JJ, Cruse CW, Rapaport D, et el. Intraoperative radio-lympho-scintigraphy improves sentinel lymph node identification for patients with melanoma. Ann Surg 1996;223(2):217-24.

33. Pieter J Tanis, Omgo E Nieweg, Renato A Valdés Olmos: History of sentinel node and validation of the technique Breast Cancer Res 2001, 3:109-112

34. Krag DN, Anderson SJ, Julian TB, Brown AM, Harlow SP, Costantino JP, Ashikaga T, Weaver DL, Mamounas EP, Jalovec LM, Frazier TG, Noyes RD, Robidoux A, Scarth HM, Wolmark N. Sentinel-lymph-node resection compared with conventional axillary-lymph-node dissection in clinically node-negative patients with breast cancer: overall survival findings from the NSABP B-32 randomised phase 3 trial. Lancet Oncol. 2010 Oct;11(10):927-33.

35. Cserni G: Az őrszemnyirokcsomók elmélete emlőrákban Magyar Tudomány, 2004/7 718. o.

36. Sarah A, McLaughlin, Mary J. Wright et al.: Prevalence of Lymphedema in Women With Breast Cancer 5 Years After Sentinel Lymph Node Biopsy or Axillary Dissection: Objective Measurements J Clin Oncol. 2008 Nov 10; 26(32): 5213-5219. [13] Boughey JC, Suman VJ, Mittendorf EA, et al.: Alliance for Clinical Trials in Oncology Sentinel lymph node surgery after neoadjuvant chemotherapy in patients with node-positive breast cancer: The ACOSOG Z1071 (Alliance) clinical trial. JAMA. 2013;310:1455-1461.

37. Lumachi F, Marino F, Zanella S, Chiara GB, Basso SM. Touch imprint cytology and frozensection analysis for intraoperative evaluation of sentinel nodes in early breast cancer. Anticancer Res 2012;32(8):3523-6.

38. Francz M, Egervari K, Szollosi Z. Intraoperative evaluation of sentinel lymph nodes in breast cancer: comparison of frozen sections, imprint cytology and immunocytochemistry. Cytopathology 2011;22(1):36-42.

39. Clarke D, Leung E, Chachlani N, et al. Intraoperative assessment of sentinel node using imprint cytology. World J Surg 2010;34(1):55-61.

40. Untch M, Huober J, Jackisch C, Schneeweiss A, Brucker SY, Dall P, Denkert C, Fasching PA, Fehm T, Gerber B, Janni W, Kühn T, Lüftner D, Möbus V, Müller V, Rody A, Sinn P, Thill M, Thomssen C, Harbeck N, Liedtke C. Initial Treatment of Patients with Primary Breast Cancer: Evidence, Controversies, Consensus: Spectrum of Opinion of German Specialists at the 15th International St. Gallen Breast Cancer Conference (Vienna 2017). Geburtshilfe Frauenheilkd. 2017 Jun;77(6):633-644. 
41. Gradishar WJ, Anderson BO, Balassanian R, Blair SL, Burstein HJ, Cyr A, Elias AD, Farrar WB, Forero A, Giordano SH, Goetz MP, Goldstein LJ, Isakoff SJ, Lyons J, Marcom PK, Mayer IA, McCormick B, Moran MS, O'Regan RM, Patel SA, Pierce LJ, Reed EC, Salerno KE, Schwartzberg LS, Sitapati A, Smith KL, Smith ML, Soliman H, Somlo G, Telli M, Ward JH, Shead DA, Kumar R. NCCN Guidelines Insights: Breast Cancer, Version 1.2017. J Natl Compr Canc Netw. 2017 Apr;15(4):433-451. http://www.nccn.org/professionals/physician_gls/pdf/breast.pdf

42. 4th ESO-ESMO International Consensus Guidelines for Advanced Breast Cancer (ABC 4) $\dagger$. Cardoso F, Senkus E, Costa A, Papadopoulos E, Aapro M, André F, Harbeck N, Aguilar Lopez B, Barrios CH, Bergh J, Biganzoli L, Boers-Doets CB, Cardoso MJ, Carey LA, Cortés J, Curigliano G, Diéras V, El Saghir NS, Eniu A, Fallowfield L, Francis PA, Gelmon K, Johnston SRD, Kaufman B, Koppikar S, Krop IE, Mayer M, Nakigudde G, Offersen BV, Ohno S, Pagani O, Paluch-Shimon S, Penault-Llorca F, Prat A, Rugo HS, Sledge GW, Spence D, Thomssen C, Vorobiof DA, Xu B, Norton L, Winer EP. Ann Oncol. 2018 Aug 1;29(8):1634-1657.

43. Lim GH, Upadhyaya VS, Acosta HA, Lim JMA, Allen JC Jr, Leong LCH. Preoperative predictors of high and low axillary nodal burden in Z0011 eligible breast cancer patients with a positive lymph node needle biopsy result. Eur J Surg Oncol. 2018 Jul;44(7):945-950.

44. Lloyd P, Theophilidou E, Newcombe RG, Pugh L, Goyal A. Axillary tumour burden in women with a fine-needle aspiration/core biopsy-proven positive node on ultrasonography compared to women with a positive sentinel node. Br J Surg. 2017 Dec;104(13):1811-1815.

45. M Liu, Y Yang, F Xie, J Guo, S Wang, H Yang, S Wang Could axillary clearance be avoided in clinically node-negative breast cancer patients with positive nodes diagnosed by ultrasound guided biopsy in the post-ACOSOG Z0011 era? PLoS One. 2019 Jan 10;14(1):e0210437.

46. Liang Y, Chen X, Tong Y, Zhan W, Zhu Y, Wu J, Huang O, He J, Zhu L, Li Y, Chen W, Shen K. Higher axillary lymph node metastasis burden in breast cancer patients with positive preoperative node biopsy: may not be appropriate to receive sentinel lymph node biopsy in the post-ACOSOG Z0011 trial era. World J Surg Oncol. 2019 Feb 20;17(1):37

47. Osorio-Silla I, Gómez Valdazo A, Sánchez Méndez JI, York E, Díaz-Almirón M, Gómez Ramírez J, Rivas Fidalgo S, Oliver JM, Álvarez CM, Hardison D, Díaz Miguel M, Lobo F, Díaz Domínguez J. Is it always necessary to perform an axillary lymph node dissection after neoadjuvant chemotherapy for breast cancer? Ann R Coll Surg Engl. 2018 Nov 13:1-7.

48. Kuehn T, Bauerfeind I, Fehm T, Fleige B, Hausschild M, Helms G, Lebeau A, Liedtke C, von Minckwitz G, Nekljudova V, Schmatloch S, Schrenk P, Staebler A, Untch M. Sentinel-lymphnode biopsy in patients with breast cancer before and after neoadjuvant chemotherapy (SENTINA): A prospective, multicentre cohort study. Lancet Oncol. 2013;14:609-618.

49. Caudle AS, Yang WT, Krishnamurthy S, Mittendorf EA, Black DM, Gilcrease MZ, Bedrosian I, Hobbs BP, DeSnyder SM, Hwang RF, Adrada BE, Shaitelman SF, Chavez-MacGregor M, Smith BD, Candelaria RP, Babiera GV, Dogan BE, Santiago L, Hunt KK, Kuerer HM. Improved axillary evaluation following neoadjuvant therapy for patients with nodepositive breast cancer using selective evaluation of clipped nodes: implementation of targeted axillary dissection. J Clin Oncol. 2016;34(10):1072-1078.

50. Caudle AS, Yang WT, Mittendorf EA, Black DM, Hwang R, Hobbs B, Hunt KK, Krishnamurthy S, Kuerer HM. Selective surgical localization of axillary lymph nodes containing metastases in patients with breast cancer: a prospective feasibility trial.JAMA Surg. 2015;150(2):137-143

51. Boughey JC, Suman VJ, Mittendorf EA, Ahrendt GM, Wilke LG, Taback B, Leitch AM, Kuerer HM, Bowling M, Flippo-Morton TS, Byrd DR, Ollila DW, Julian TB, McLaughlin SA, McCall 
L, Symmans WF, Le-Petross HT, Haffty BG, Buchholz TA, Nelson H, Hunt KK Alliance for Clinical Trials in Oncology Sentinel lymph node surgery after neoadjuvant chemotherapy in patients with node-positive breast cancer: The ACOSOG Z1071 (Alliance) clinical trial. JAMA. 2013;310:1455-1461.

52. Boughey JC, Ballman KV, Le-Petross HT, et al: Identification and resection of clipped node decreases the false-negative rate of sentinel lymph node surgery in patients presenting with nodepositive breast cancer (T0-T4, N1-N2) who receive neoadjuvant chemotherapy: Results from ACOSOG Z1071 (Alliance). Ann Surg

53. Pilewskie M, Mautner SK, Stempel M, Eaton A, Morrow M. Does a Positive Axillary Lymph Node Needle Biopsy Result Predict the Need for an Axillary Lymph Node Dissection in Clinically Node-Negative Breast Cancer Patients in the ACOSOG Z0011 Era? Ann Surg Oncol. 2016; 23: 1123-1128.

54. Pilewskie M, Jochelson M, Gooch JC, Patil S, Stempel M, Morrow M. Is Preoperative Axillary Imaging Beneficial in Identifying Clinically Node-Negative Patients Requiring Axillary Lymph Node Dissection? J Am Coll Surg. 2016 Feb;222(2):138-45.

55. Pilewskie M, Zabor EC, Mamtani A, Barrio A, Stempel M, Morrow M. The Optimal Treatment Plan to Avoid Axillary Lymph Node Dissection in Early-Stage Breast Cancer Patients Differs by Surgical Strategy and Tumor Subtype. Ann Surg Oncol. 2017 Nov;24(12):3527-3533.

56. Nguyen TT, Hieken TJ, Glazebrook KN, Boughey JC. Localizing the Clipped Node in Patients with Node-Positive Breast Cancer Treated with Neoadjuvant Chemotherapy: Early Learning Experience and Challenges. Nguyen TT, Hieken TJ, Glazebrook KN, Boughey JC. Ann Surg Oncol. 2017 Oct;24(10):3011-3016. 
I 


\title{
Is intraoperative touch imprint cytology indicated in the surgical treatment of early breast cancers?
}

\author{
Z. Horváth ${ }^{\text {a }}$, A. Paszt ${ }^{\text {a }}$, Z. Simonka ${ }^{\text {a }}$, M. Látos ${ }^{\text {a }}$, V. Oláh ${ }^{\text {a }}$, \\ D. Nagyszegi ${ }^{\text {a }}$, L. Kaizer ${ }^{\text {b }, ~ Z . ~ F e j e s ~}{ }^{\text {b }}$, S. Hamar ${ }^{\text {b }}$, E. Csörgö ${ }^{b}$, \\ K. Ormándi ${ }^{\mathrm{c}}$, M. Lázár ${ }^{\mathrm{c}}$, G. Lázár ${ }^{\mathrm{a}, *}$ \\ ${ }^{a}$ Department of Surgery, University of Szeged, Albert Szent-Györgyi Clinical Center, Semmelweis u. 8., Szeged, \\ H-6720, Hungary \\ ${ }^{\mathrm{b}}$ Department of Pathology, University of Szeged, Albert Szent-Györgyi Clinical Center, Allomás u. 2., Szeged, \\ H-6720, Hungary \\ ${ }^{\mathrm{c}}$ Diagnoscan Hungary - Szeged, Semmelweis u. 6., Szeged, H-6725, Hungary
}

Accepted 10 January 2017

Available online 18 January 2017

\begin{abstract}
Introduction: Intraoperative touch imprint cytology (TIC) of the sentinel lymph node(s) (SLN(s)) in the treatment of breast cancer has significantly reduced the number of axillary block dissections (ABD) required during second surgeries. Based on recent studies, ABD was not considered necessary if the presence of tumor cells/micrometastasis was confirmed in the SLN(s) or in the case of macrometastases in a patient group meeting the inclusion criteria for the ACOSOG Z0011 study. Our aim was to determine the sensitivity and usefulness of TIC with regard to these results.

Methods: TICs of the SLN(s) were examined in 1168 patients operated on for breast cancer. The method was also analyzed retrospectively based on the guidelines for the Z0011 study. During TIC, new samples were cut every $250 \mu \mathrm{m}$; impression smears were evaluated after being stained with hematoxylin eosin.

Results: TIC confirmed metastasis in 202 cases (202/1168, 17.29\%). Metastasis was confirmed in SLN(s) in 149 additional cases during a final histological examination. The sensitivity of TIC was found to be $57.18 \%$, and its specificity was $99.63 \%$. An analysis was then performed except for cases that met the inclusion criteria for the Z0011 study and with metastasis smaller than 2 mm (micrometastasis/isolated tumor cells) considered to be positive during intraoperative cytology. The sensitivity of the method decreased to $34.23 \%$, while its specificity was still high at $99.76 \%$.

Conclusions: Based on the new guidelines for ABD, imprint cytology cannot be considered a beneficial and cost-effective intervention in the surgical treatment of early breast cancer.

(C) 2017 Elsevier Ltd, BASO The Association for Cancer Surgery, and the European Society of Surgical Oncology. All rights reserved.
\end{abstract}

\section{Introduction}

The introduction of sentinel lymph node biopsy (SLNB) in the treatment of early breast cancer 20 years ago significantly reduced the number of radical surgical interventions and the number of axillary block dissections (ABD). ${ }^{1,2}$ Intraoperative analysis of the sentinel lymph node(s) has been used increasingly, as surgeries performed in two sessions can be avoided with this method in most cases. ${ }^{1,3}$

\footnotetext{
* Corresponding author. Department of Surgery, University of Szeged, Albert Szent-Györgyi Clinical Center, Szőkefalvi-Nagy B. u. 6., Szeged, H-6720, Hungary. Fax: +36 62545701

E-mail addresses: horvath.zoltan@med.u-szeged.hu (Z. Horváth), paszt.attila@med.u-szeged.hu (A. Paszt), simonka.zsolt@med.u-szeged.hu (Z. Simonka), latos.melinda@med.u-szeged.hu (M. Látos),viktorolah2@gmail.com (V. Oláh), nagyszegi.dora@gmail.com (D. Nagyszegi), kaizer.laszlo@med.u-szeged.hu (L. Kaizer), fejes.zsuzsanna@med.u-szeged.hu (Z. Fejes), hamar.sandor@med.u-szeged.hu (S. Hamar), csorgo.erika@med.u-szeged.hu (E. Csörgő), ormikati@gmail.com (K. Ormándi), lazarmate@gmail.com (M. Lázár), lazar.gyorgy@med.u-szeged.hu (G. Lázár).
} 
Intraoperative histological examinations include imprint cytology, frozen section histology and a nucleic acid amplification study. The specificity and sensitivity of these examinations are similar. The sensitivity of the nucleic acid amplification study is $76.9-98.2 \%$, and that of frozen section histology and imprint cytology varies between 68.49 and $98.81 \%$. The specificity of all three methods is considered almost $100 \% .^{4-7}$

Surgical treatment of the axilla has changed significantly, particularly with regard to the indication for supplementary ABD. Based on the results of several prospective studies, ABD is not indicated for positive sentinel lymph nodes containing isolated tumor cells (ITC, $<0.2 \mathrm{~mm}$ ) and micrometastases $(<2 \mathrm{~mm})$, adjuvant therapy being sufficient. ${ }^{8-10}$ The results were also described in several international guidelines. ${ }^{9,11}$ Axillary block dissection is not necessarily required for patients with wide excision and sentinel lymph node biopsy for stage $T_{1}$ or $T_{2}$ breast cancer with sentinel lymph nodes containing no more than 1-2 macrometastases, according to the ACOSOG Z0011 study published in 2011 (neoadjuvant therapy is an exclusion criterion as well), as additional surgical treatment neither increases survival significantly nor reduces the incidence of axillary recurring tumors. ${ }^{8}$ In these cases, adjuvant systemic treatment and complete irradiation of the breast are sufficient. ${ }^{8,11-17}$ According to the ACOSOG Z0011 study criteria, a consensus conference held in St. Gallen in 2013, the Guidelines of the American Association of Oncology $(\mathrm{NCCN})$ and axillary block dissection may be omitted. $8,13,14$

According to several studies, ABD is an equivalent therapeutic alternative to targeted axillary radiation. ${ }^{15-17}$ Knowledge of treatment alternatives and participation in treatment selection represent a growing demand among patients. However, in the case of axillary block dissection performed for positive imprint cytology, patients cannot participate in the therapeutic decision.

In conclusion, the routine use of imprint cytology should be reconsidered. In our study, imprint cytology results were examined and analyzed retrospectively based on new national guidelines on the treatment of the axilla. Moreover, we analyzed the cost and time of breast surgery taking into account the necessity of imprint cytology.

sensitivity $=$ realpositivecases/realpositivecases + falsenegativecases

\section{Patients and methods}

Between 2008 and 2014, a total of 1673 patients underwent surgery in our institution for invasive breast cancer and other breast malignancies. In this period, 1168 patients who were suffering from consecutive early invasive breast carcinoma and whose preoperative axillary US + FNA did not show axillary lymph node metastasis were examined with imprint cytology of the SLN(s).

Sentinel lymph nodes were removed with the double tracer method published by Albertini in $1996 .{ }^{18}$ On the day before the surgery (but at least four hours before the surgery), human colloidal albumin was administered with isotope $(99 \mathrm{mTc})$ tracing under ultrasound or X-ray guidance near the lesion. A lymphoscintigraphic (static) examination was then performed to determine the projection of SLN(s) and lymphatic drainage. The patent blue dye was periareolarly. The SLN(s) were identified with a manual gamma camera.

The technique for touch imprint cytology (TIC) was as follows: the cut surface of the fresh sample prepared from a lymph node ( $250 \mu \mathrm{m}$ slices) was pressed on a slide, and then an impression smear was prepared. The resulting imprint cut surfaces were fixed in 95\% ethanol for 5-6 s, and the samples were evaluated after hematoxylin eosin staining. Every SLN underwent a standard histological examination later.

We allocated the sensitivity and specificity of TIC based on the intraoperative and final histological result. Based on the final histological examination of the sentinel lymph no$\mathrm{de}(\mathrm{s})$, we selected patients in whose cases performing an $\mathrm{ABD}$ is no longer justified according to the new international recommendations (ITC, micro- and macrometastases, which meet the criteria for ACOSOG Z0011) and thus there is no need for intraoperative lymph node analysis either. Based on these data, the imprint cytology results were re-evaluated and compared with non-modified data.

\section{Statistics}

We studied the sensitivity and specificity of imprint cytology with the scheme below:

specificity $=$ realnegativecases $/$ realnegativecases + falsepositivecases 
We used the SPSS (Statistical Package for the Social Sciences) programme for comparing the operating time. We analyzed the data two-sample T-test. The study has been approved by the local Ethics Committee.

\section{Results}

In our Department, TIC was performed for invasive breast tumor in 1168 cases during the period under examination. The average age of the patients was $58.63(25-88)$ years. TIC was positive in 202 cases in $17.29 \%(202 / 1168)$ of the cases. A total of 2101 lymph nodes were sent for imprint cytology, which is an average of 1.8 (1-6) lymph nodes per patient.

During a final histological examination of the samples, metastasis was found in 149 additional previously (intraoperatively) negative sentinel lymph nodes (false negative cases: 149/1168 [12.75\%]), and metastasis was not confirmed in three cases found to be positive with imprint cytology (false positive cases: $3 / 149$ [0.25\%]). The sensitivity of the imprint cytology was $57.18 \%$, with a specificity of $99.63 \%$ (Table 1 ).

A total of 202 axillary block dissections were performed in one session, and then 80 block dissections were performed on a separate occasion. In 64 cases, an ABD was not performed, as the patient had not given his consent for the intervention, the patient had chosen adjuvant chemotherapy, or the oncoteam had not recommended additional surgery due to the presence of micrometastasis.

At that point, patients meeting the inclusion criteria for the Z0011 study $(\mathrm{n}=117)$ and seven patients not meeting the criteria for Z0011 but with micrometastasis $(\mathrm{n}=7)$ were excluded from the positive cases by intraoperative examination (Tables 1 and 2), and then the sensitivity and specificity of the method were recalculated.

After screening, 78 positive (number of positive cases $=202$ minus number of patients meeting criteria

Table 1

Imprint cytology results (1 May 2008-31 Dec 2014).

\begin{tabular}{lll}
\hline & Total & $\%$ \\
\hline Number of patients & 1168 & 100 \\
Imprint cytology results & & \\
$\quad$ Intraoperative (positive) & 202 & 17.3 \\
$\quad$ Intraoperative (negative) & 966 & 82.7 \\
$\quad$ False negative & 149 & 12.76 \\
$\quad$ False positive & 3 & 0.25 \\
Number of positive final histological examinations & 348 & 29.79 \\
Number of negative final histological examinations & 820 & 70.21 \\
Type of surgery & & \\
$\quad$ Excision & 883 & 75.6 \\
$\quad$ Mastectomy & 285 & 24.4 \\
Average tumor size (mm) & 19.61 & \\
Average number of SLNBs & 1.8 & \\
ABDs & 284 & 24.32 \\
In one session & 204 & 17.47 \\
Supplementary & 80 & 6.85 \\
\hline
\end{tabular}

Table 2

Patients meeting the criteria for the Z0011 study and with a positive imprint cytology.

\begin{tabular}{lll}
\hline & Total & $\%$ \\
\hline $\begin{array}{l}\text { Number of patients } \\
\text { Imprint cytology results }\end{array}$ & 117 & 100 \\
$\quad$ Positive & 116 & 99.15 \\
$\quad$ Negative & 1 & 0.85 \\
$\quad$ False negative & 0 & \\
$\quad$ False positive & 1 & 0.85 \\
Number of final, positive histological examinations & 116 & \\
Type of surgery & & \\
$\quad$ Excision & 117 & 100 \\
$\quad$ Mastectomy & 0 & 0 \\
Average tumor size (mm) & 20.56286 \\
Average number of SLNBs & 1.97 & \\
ABDs & & \\
Performed in one session & 111 & 94.87 \\
Supplementary & 2 & 1.71 \\
Not performed & \\
\hline a Axillary block dissection was not performed in four cases when a pa- \\
tient made a request in advance to that effect or in the presence of \\
micrometastases.
\end{tabular}

for Z0011 [ $\mathrm{n}=117]$ and number of patients not meeting criteria for Z0011 but with micrometastasis [n $=7]$ ), two false positive, 149 false negative and 966 negative cases were found in the repeated imprint cytology group. Sensitivity fell to $34.23 \%$, and specificity remained $99.76 \%$ (Table 3).

As can be seen on Table 4, axillary block dissection was performed in 284 cases, but, based on the new guidelines, only 105 cases were indicated. 179 cases, that is, $15.32 \%$ of the cases, were performed unnecessarily.

As the results were processed, the average size of the metastases and the distribution of micro- and macrometastases in false negative and positive cases were examined as well (Table 5). In positive cases, the average size of the micrometastases was $1.52 \mathrm{~mm}$, while that of the macrometastases was $8.33 \mathrm{~mm}$. The average size of the micrometastases was $1.1 \mathrm{~mm}$, while that of the macrometastases was $4.79 \mathrm{~mm}$ in the false negative group. Therefore, it can be concluded that imprint cytology cannot be considered a sensitive intervention for surgeries on smaller metastases.

The costs of ABDs performed with imprint cytology and with supplementary imprint cytology were compared in financial terms. (The costs of SLNBs and ABDs performed during surgery are similar.) During imprint cytology, an average of five cut surfaces is prepared of the lymph node. A cut surface costs $€ 32.50$. The average price of histology performed during surgery is therefore $1.8^{*} € 32.50$, that is, €58.52. An ABD costs $€ 431.17$. Based on the results, the 1168 imprint cytologies cost $€ 68,359.23$, while the 76 supplementary ABDs cost $€ 32,768.49$. Therefore, the difference is $€ 35,586.73$. Patient hospital stay after ABD is longer (about one day) and more out-patient visits are required, thus further increasing the difference in expenses. This represents an extra charge of about $€ 100$ 
Table 3

Results modified in accordance with the criteria.

\begin{tabular}{lllll}
\hline & Imprint (all cases) & $\begin{array}{l}\text { Cases meeting } \\
\text { Z0011 criteria }\end{array}$ & $\begin{array}{l}\text { Cases not meeting Z0011 criteria but } \\
\text { involving micrometastasis }\end{array}$ & Results recalculated \\
\hline $\begin{array}{l}\text { Number of patients } \\
\quad \text { Imprint }\end{array}$ & 1168 & 117 & 7 & 1168 \\
$\quad \begin{array}{l}\text { Positive } \\
\text { Negative }\end{array}$ & 202 & 117 & 7 & 78 \\
Final histology & 966 & 0 & 0 & 966 \\
$\quad$ Positive & 348 & 116 & 7 & 225 \\
False positive & 3 & 1 & 0 & 2 \\
False negative & 149 & 0 & 0 & 149 \\
\hline
\end{tabular}

Table 4

Distribution of axillary block dissections.

\begin{tabular}{llll}
\hline & & Total number of ABDs \\
\hline Imprint & Supplementary ABDs & 80 & 284 \\
& ABDs performed in one session & 204 & 2 \\
Positive cases according to Z0011 criteria & Supplementary ABDs & 114 & 112 \\
& ABDs performed in one session & 56 & 58 \\
False negative cases according to Z0011 criteria & Supplementary ABDs & 2 & 0 \\
& ABDs performed in one session & 7 & 7 \\
Cases not meeting Z0011 criteria but involving micrometastasis & Supplementary ABDs & 22 & 105 \\
& ABD performed in one session & 83 & \\
\hline
\end{tabular}

per patient (based on Hungarian expenses). We have examined the average duration of breast surgery with and without imprint cytology. Surgeries were longer by approximately $1.6-5$ min when cytology was used, and the difference was non-significant (data not shown).

\section{Discussion}

The introduction of SLNB has been a milestone in the treatment of early breast cancer, as it has significantly reduced the number of axillary block dissections and similarly improved staging and oncology/complex treatment of breast cancers. Simultaneously, intraoperative examination of the sentinel lymph node(s) has been introduced, and, as a result, the number of surgeries performed in two stages and, consequently, both the burden on the patients and surgical costs have decreased.

According to recent studies and guidelines, in cases meeting certain criteria, such as isolated tumor cells, sentinel lymph nodes with micrometastasis and no more than two macrometastases, ABD may be omitted, as it does not increase the risk of overall mortality and locally recurring cancer. ${ }^{8,9,11}$ Similarly, the indication for ABD is reduced by clinical studies supporting the fact that axillary radiation is an alternative treatment option to surgery, but it is associated with lower morbidity. ${ }^{15-17}$ Axillary radiotherapy does not pose an increased risk to survival and locally recurring cancer, and the incidence of lymphedema, which is primarily responsible for morbidity, is significantly decreased as well. Another important factor is the fact that in the case of axillary block dissection performed for positive imprint cytology, the patient is unable to participate in the therapeutic decision and choose from among therapeutic options.

These factors suggest a reconsideration of the routine use of imprint cytology. Based on our results, the sensitivity of imprint cytology is $57.18 \%$, its specificity is $99.63 \%$, and these values are consistent with international data. (The

Table 5

Lymph node metastases in false negative and false positive cases.

\begin{tabular}{|c|c|c|c|c|c|}
\hline & $\begin{array}{l}\text { Sizes of } \\
\text { metastases (mm) }\end{array}$ & $\begin{array}{l}\text { Number of } \\
\text { metastases }\end{array}$ & $\begin{array}{l}\text { Distribution in \% of } \\
\text { all metastases }\end{array}$ & $\begin{array}{l}\text { Distribution in \% of } \\
\text { all micro-metastases }\end{array}$ & $\begin{array}{l}\text { Distribution in } \% \text { of } \\
\text { all macro-metastases }\end{array}$ \\
\hline \multicolumn{6}{|l|}{ Positive cases } \\
\hline Micrometastases & 1.52 & 13 & 3.73 & 15.85 & \\
\hline Macrometastases & 8.33 & 187 & 53.58 & & 70.3 \\
\hline \multicolumn{6}{|l|}{ False negative cases } \\
\hline Micrometastases & 1.10 & 69 & 19.77 & 84.15 & \\
\hline Macrometastases & 4.79 & 80 & 22.92 & & 29.7 \\
\hline
\end{tabular}


sensitivity of imprint cytology varies between 68.49 and $98.81 \%$, with a specificity of approximately $100 \%){ }^{5,19-21}$ With regard to metastasis sizes and distribution, imprint cytology is less suited to detecting metastases of $2 \mathrm{~mm}$ or smaller, with $84.15 \%$ of micrometastases remaining undetected, but $70.3 \%$ of macrometastases can be detected with this method.

However, according to the latest guidelines, the sensitivity of imprint cytology (based on cases with therapeutic consequences) is only $34.23 \%$ (with unchanged specificity). This sensitivity value is so low that the usability of this method is questionable. ABD was only indicated in $9 \%$ of the patients in the period under examination (105/ 1168). However, based on the new guidelines, supplementary lymph node dissection was performed "unnecessarily" in $15.32 \%$ of the patients $(179 / 1168)$.

It is not insignificant that imprint cytology increased surgical costs and the duration of surgery unnecessarily in a large percentage of the patients (91\%). Imprint cytology and surgical costs are significantly higher in Western Europe and the United States; differences in costs (cost effectiveness) are therefore more significant in those regions (due to the operational cost of the surgery and the surgeon's fee, these interventions cost at least $€ 32-100$ per surgery, totaling $€ 37,376-116,800$ for 1168 patients. ${ }^{22}$ )

The price of imprint cytology of a lymph node in the United States in 2010 was (the dollar equivalent of) $€ 57 .^{23}$ Based on this data, in our case, the total cost would be $€ 119,832$. If we use the latest intraoperative histological diagnostic method, nucleic acid amplification, it costs $€ 172.50$ to examine a lymph node, based on data from a French survey. ${ }^{24}$ The cost for the total patient population was $€ 362,664$. Intraoperative histological examinations are less effective $e^{4,6}$ and significantly increase treatment costs for patients operated on for early breast cancer.

Our study shows that axillary block dissection is only necessary in the treatment of the axillary region in an increasingly smaller group of patients (9\%), and this percentage will further decrease with more extensive use of alternative axillary radiotherapy.

Based on our results, imprint cytology of the sentinel lymph node(s) in patients operated on for malignant breast cancer has no confirmed benefits based on the current guidelines, and its routine use is not indicated. According to the latest international guidelines, intraoperative examination of the sentinel lymph node(s) may be indicated in the case of mastectomy (when postoperative radiotherapy is not planned) and after neoadjuvant therapy, as ABD is still indicated in these cases.

\section{Conflict of interest statement}

The authors have no conflict of interest or financial disclosure.

\section{References}

1. Giuliano AE, Kirgan DM, Guenther JM, et al. Lymphatic mapping and sentinel lymphadenectomy for breast cancer. Ann Surg 1994;220:391401.

2. Giuliano AE, Dale PS, Turner RR, et al. Improved axillary staging of breast cancer with sentinel lymphadenectomy. Ann Surg 1995;222: 394-401.

3. Krag DN, Weaver DL, Alex JC, Fairbank JT. Surgical resection and radiolocalization of the sentinel lymph node in breast cancer using a gamma probe. Surg Oncol 1993;2:335-40.

4. Le Frère-Belda MA, Bats AS, Gillaizeau F, et al. Diagnostic performance of one-step nucleic acid amplification for intraoperative sentinel node metastasis detection in breast cancer patients. Int J Cancer 2012;130:2377-86.

5. Safai A, Razeghi A, Monabati A, Azarpira N, Talei A. Comparing touch imprint cytology, frozen section analysis, and cytokeratin immunostaining for intraoperative evaluation of axillary sentinel lymph nodes in breast cancer. Indian J Pathol Microbiol 2012;55: 183-6.

6. Cserni G. Intraoperative analysis of sentinel lymph nodes in breast cancer by one-step nucleic acid amplification. J Clin Pathol 2012; 65:193-9.

7. Pathmanathan N, Renthawa J, French JR, et al. Intraoperative sentinel lymph node assessment in breast cancer: a comparison of rapid diagnostic method based on CK19 mRNA expression and imprint cytology. ANZ J Surg 2014;84:730-4.

8. Giuliano AE, McCall L, Beitsch P, et al. Locoregional recurrence after sentinel lymph node dissection with or without axillary dissection in patients with sentinel lymph node metastases: the American College of Surgeons Oncology Group Z0011 randomized trial. Ann Surg 2010;252:426-32.

9. Goldhirsch A, Wood WC, Coates AS, et al. Strategies for subtypes-dealing with the diversity of breast cancer: highlights of the St. Gallen International Expert Consensus on the Primary Therapy of Early Breast Cancer 2011. Ann Oncol 2011;22:1736-47.

10. Solá M, Alberro JA, Fraile M, et al. Complete axillary lymph node dissection versus clinical follow-up in breast cancer patients with sentinel node micrometastasis: final results from the multicenter clinical trial AATRM 048/13/2000. Ann Surg Oncol 2013;20:120-7.

11. AGO, DGS, SGS, ÖGS, Panelists, Executive Board Members. German, Austrian and Swiss consensus conference on the diagnosis and local treatment of the axilla in breast cancer. Eur $J$ Cancer 2013;49:2277-83.

12. Galimberti V, Cole BF, Zurrida S, et al. Axillary dissection versus no axillary dissection in patients with sentinel-node micrometastases (IBCSG 23-01): a phase 3 randomised controlled trial. Lancet Oncol 2013;14:297-305.

13. Goldhirsch A, Winer EP, Coates AS, et al. Personalizing the treatment of women with early breast cancer: highlights of the St Gallen International Expert Consensus on the Primary Therapy of Early Breast Cancer 2013. Ann Oncol 2013;24:2206-23.

14. National Comprehensive Cancer Network. Clinical practice guidelines in oncology - breast cancer version 1.2016. [cited 2016 May10]. Available from: URL: http://www.nccn.org/professionals/physician_ gls/pdf/breast.pdf.

15. Rutgers EJ, Donker M, Straver ME, et al. Radiotherapy or surgery of the axilla after a positive sentinel node in breast cancer patients: final analysis of the EORTC AMAROS trial (10981/22023). J Clin Oncol 2013;31(Suppl). abstr LBA1001.

16. Donker M, van Tienhoven G, Straver ME, et al. Radiotherapy or surgery of the axilla after a positive sentinel node in breast cancer (EORTC 10981-22023 AMAROS): a randomised, multicentre, openlabel, phase 3 non-inferiority trial. Lancet Oncol 2014;15:1303-10.

17. Sávolt A, Polgár Cs, Musonda P, et al. Does the result of completion axillary lymph node dissection influence the recommendation for 
adjuvant treatment in sentinel lymph node-positive patients? Clin Breast Cancer 2013;13:364-70.

18. Albertini JJ, Cruse CW, Rapaport D, et al. Intraoperative radiolympho-scintigraphy improves sentinel lymph node identification for patients with melanoma. Ann Surg 1996;223:217-24.

19. Lumachi F, Marino F, Zanella S, Chiara GB, Basso SM. Touch imprint cytology and frozen-section analysis for intraoperative evaluation of sentinel nodes in early breast cancer. Anticancer Res 2012;32:3523-6.

20. Francz M, Egervari K, Szollosi Z. Intraoperative evaluation of sentinel lymph nodes in breast cancer: comparison of frozen sections, imprint cytology and immunocytochemistry. Cytopathology 2011;22:36-42.

21. Clarke D, Leung E, Chachlani N, et al. Intraoperative assessment of sentinel node using imprint cytology. World J Surg 2010;34:55-61.
22. Genta F, Zanon E, Camanni M, et al. Cost/accuracy ratio analysis in breast cancer patients undergoing ultrasound-guided fine-needle aspiration cytology, sentinel node biopsy, and frozen section of node. World J Surg 2007;31:1155-63.

23. Kamiński JP, Case D, Howard-McNatt M, Geisinger KR, Levine EA. Sentinel lymph node intraoperative imprint cytology in patients with breast cancer-costly or cost effective? Ann Surg Oncol 2010;17: 2920-5.

24. Raia-Barjat T, Trombert B, Khaddage A, et al. OSNA (one-step nucleic acid amplification) sentinel lymph node intraoperative molecular analysis in breast cancer: a cost-benefit analysis. Med Oncol 2014;31: 322. 


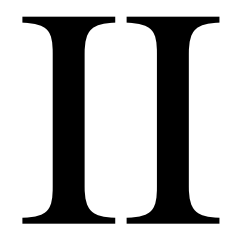




\title{
Is axillary lymph node dissection necessary for positive preoperative aspiration cytology lymph node results?
}

\author{
Z. Horváth ${ }^{\text {a }}$, A. Paszt ${ }^{a}$, Z. Simonka a, M. Látos a , L. Kaizer ${ }^{\text {b }}$, S. Hamar ${ }^{\text {b }}$, A. Vörös ${ }^{\text {b }}$, \\ K. Ormándi ${ }^{\mathrm{c}}$, Z. Fejes ${ }^{\mathrm{c}}$, G. Lázár ${ }^{\mathrm{a},{ }^{*}}$ \\ ${ }^{a}$ Department of Surgery, University of Szeged, Albert Szent-Györgyi Clinical Centre, H-6725, Szeged, Semmelweis u. 8, Hungary \\ ${ }^{\mathrm{b}}$ Department of Pathology, University of Szeged, Albert Szent-Györgyi Clinical Centre, H-6725, Szeged, Állomás u. 2, Hungary \\ ${ }^{c}$ Affidea Hungary - Szeged, University of Szeged, Albert Szent-Györgyi Clinical Centre, H-6725, Szeged, Semmelweis u. 6/A, Hungary
}

\section{A R T I C L E I N F O}

\section{Article history:}

Received 5 August 2019

Received in revised form

17 October 2019

Accepted 31 October 2019

Available online $\mathrm{xxx}$

\section{Keywords:}

Breast cancer

Axillary lymph node dissection

Neoadjuvant therapy

Axillary metastasis

\begin{abstract}
A B S T R A C T
Introduction: Based on international guidelines, axillary lymph node dissection (ALND) is recommended in cases of breast cancer if preoperative examinations confirm axillary metastasis. We examined which set of preoperative parameters might render ALND unnecessary.

Patients and methods: Preoperative examinations (axillary ultrasound and aspiration cytology) confirmed axillary metastasis in 190 cases out of 2671 patients with breast cancer; primary ALN dissection was performed on these patients with or without prior neoadjuvant therapy. The clinicopathological results were analysed to determine which parameter might predict the presence of no more than 2 or 3 metastatic ALNs.

Results: The final histological examination confirmed 1-3 metastatic lymph nodes in ALND samples in 116 cases and over 3 metastatic lymph nodes in 74 cases.

For patients receiving neoadjuvant therapy (59 out of the 190 cases), if the size of the primary tumour was $2 \mathrm{~cm}$ or smaller and/or the metastatic ALN was $15 \mathrm{~mm}$ or smaller, then the patient was likely to have no more than 3 positive ALNs (stage N0-1 disease) $(\mathrm{p}<0.001$ ). If the patient did not receive neoadjuvant therapy, stage N2 or N3 disease was very likely. No correlation was found between other clinicopathological characteristics of the tumour and involvement of the ALNs.

Conclusion: Axillary lymph node dissection is not necessary for selected breast cancer patients with axillary metastasis receiving neoadjuvant therapy. In these cases, sentinel lymph node biopsy with or without radiation therapy and close follow-up may serve as adequate therapy.
\end{abstract}

() 2019 Published by Elsevier Ltd.

\section{Introduction}

Surgical treatment of patients with breast cancer and positive axillary lymph nodes is becoming less and less invasive.

Based on results from the ACOSOG Z0011 study, axillary lymph node dissection (ALND) is not required even in cases with 1 or 2 axillary sentinel lymph nodes involving macrometastasis if the

\footnotetext{
* Corresponding author.

E-mail addresses: horvath.zoltan@med.u-szeged.hu, doctor.horvath@gmail.com (Z. Horváth), paszt.attila@med.u-szeged.hu (A. Paszt), simonka.zsolt@med.uszeged.hu (Z. Simonka), latosmeli@gmail.com, latos.melinda@med.u-szeged.hu (M. Látos), kaizer.laszlo@med.u-szeged.hu (L. Kaizer), hamar.sandor@med.uszeged.hu (S. Hamar), voros.andras@med.u-szeged.hu (A. Vörös), ormikati@gmail. com (K. Ormándi), fejes.zsuzsanna@med.u-szeged.hu (Z. Fejes), lazar.gyorgy@ med.u-szeged.hu (G. Lázár).
}

patient meets the inclusion criteria for the study [1,2]. This recommendation has been approved by international and Hungarian consensus conferences as well $[3,4]$.

Patients with ALN metastasis confirmed by preoperative examinations represent a separate treatment group. ALND must be performed on these patients if surgical treatment is required, as well as in patients with over two positive sentinel lymph nodes who do not meet the Z0011 selection criteria (i.e. > 2 sentinel lymph nodes containing metastasis, mastectomy, or breast conservation without whole-breast radiotherapy). Axillary ultrasound is a key method for diagnosing axillary metastasis, and a positive axillary ultrasound result also necessitates aspiration cytology. The sensitivity of axillary ultrasound ranges from 25 to $71 \%$ depending on the immunohistochemical status of the tumour [5]; sensitivity increases to approximately $70-80 \%$ with the addition of fine needle aspiration cytology (FNAC) [6-9]. 
In cases where a lymph node is found to be positive with aspiration cytology, systemic neoadjuvant therapy is performed on some patients. Based on international results, complete axillary pathological regression occurs in a significant portion of these patients [10-12].

A small number of ongoing prospective studies (the SAKK 23/16 TAXIS trial, ALLIANCE A011202, and NSABP B-51/RTOG 1304 trial) are investigating the role of radiotherapy, and less invasive axillary surgery (tailored axillary surgery, or sentinel lymph node biopsy, SLNB) after neoadjuvant chemotherapy. Similarly, we know that in a portion of patients, metastasis is only present in the sentinel lymph node. A study published in 2017 confirmed that axillary lymph node dissection is may not necessarily be indicated as the first surgery; SLNB is recommended instead if the primary tumour is $\leq 2 \mathrm{~cm}$ as confirmed by a preoperative breast ultrasound examination, no more than one lymph node in the axillary region is confirmed positive with aspiration cytology, and the patient is not receiving neoadjuvant therapy [13].

Therefore, in our study, we were looking for correlations between the preoperative axillary ultrasound examination and clinicopathological factors to be able to predict not only the presence, but also the severity of axillary metastasis (slight or severe). A further aim of our study was to decide in advance when ALND is required and in which cases SLNB is sufficient based on the results of preoperative examinations.

\section{Patients and methods}

Pre- and postoperative data from 2671 cases where surgery was performed due to early invasive breast tumour were evaluated in the Department of Surgery, Faculty of Medicine, University of Szeged between 1 January 2007 and 31 December 2017. Our study was a retrospective analysis of a prospectively maintained database (Fig. 1).
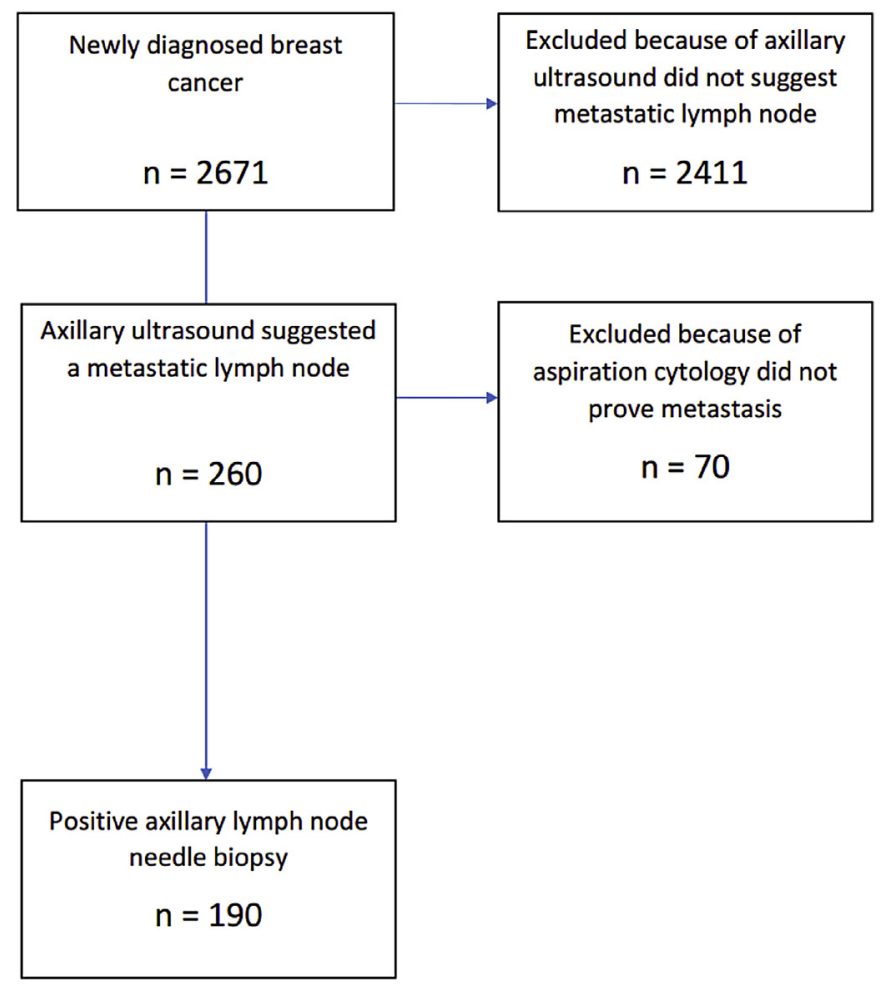

Fig. 1. Flowchart of patient selection.
Mandatory items of the complex breast examination included a physical examination, an ultrasound examination, a mammogram and histology.

Both axillae were examined - axilla levels I, II and III included during the axillary ultrasound. All the enlarged and abnormal lymph nodes were recorded in the description. In positive axillary ultrasound examination cases, aspiration cytology sampling was also performed. Axillary ultrasound was considered positive if the eccentric or concentric cortical region of the lymph node was larger than $2.5 \mathrm{~mm}$, the adipose hilum was missing, the lymph node was morphologically rounded, or its blood supply was increased. In cases where axillary ultrasound and aspiration cytology were positive, neoadjuvant systemic therapy was also administered in some patients. Neoadjuvant therapy was administered in accordance with current international practice, primarily to be able to remove tumours originally found to be oncologically inoperable and to be able to perform breast-conserving surgery instead of a mastectomy.

Surgical treatment. Our goal was to provide locoregional tumour control and precise locoregional staging. With an aesthetic outcome also taken into consideration, breast-conserving surgery was performed whenever possible. ROLL (radio-guided occult lesion localisation) and dual labelling were used to localise breast tumours and the sentinel lymph node. At least $4 \mathrm{~h}$ before the surgery, isotope $(99 \mathrm{mTc})$ labelled human colloidal albumin was administered into the lesion, which was followed by lymphoscintigraphy to determine the projection of the sentinel lymph node and that of the lymphatic drainage. As a first step during surgery, Patentblau dye was administered around the areola, and then a manual gamma probe was used to remove the tumour and the sentinel lymph node(s) during the same procedure approximately $10 \mathrm{~min}$ later. ALND was primarily performed with or without prior neoadjuvant therapy if preoperative examinations confirmed the presence of even one ALN metastasis.

Patients were divided into two large groups on the basis of a final histological examination of the axillary lymph nodes. One group consisted of patients with no more than 3 positive lymph nodes (N0-1) in accordance with the TNM classification; the other group consisted of patients with 4 or more positive lymph nodes (N2-3). Due to the maximum of 2 positive lymph nodes described in the Z0011 study, we formed an additional group with no more than 2 metastatic lymph nodes (Z1) and another with 3 or more metastatic lymph nodes (Z2). The clinical, radiological and histological results of these groups were analysed as well.

In our study, clinicopathological results (histological and immunohistochemical status, tumour location, tumour size before and after surgery, size and number of abnormal lymph nodes described by ultrasound examination, cytology of the axillary lymph node, neoadjuvant therapy, and final axillary histological lymph node status) were compared. We aimed to ascertain which preoperative examination results may be used to predict the presence of a maximum of only 2 or 3 metastatic lymph nodes in the axillary region.

Statistics. IBM SPSS Statistics v22 software was used for statistical analysis in our study. Continuous variables were presented as mean and standard deviation, while categorical variables were presented as case number and percentages. The chi-square test followed by logistic regression was used to evaluate the cumulative effect of the variables on axillary status. The difference was considered statistically significant in cases where $\mathrm{p}<0.05$ with a confidence interval of $95 \%$.

\section{Results}

Surgical intervention was performed in 2671 invasive breast 
tumour cases (average age: 59.73 years). In 260 cases, axillary ultrasound suggested a metastatic lymph node; therefore, aspiration cytology sampling was performed. In 190 cases, pathology reports suggested metastasis; in these cases, ALND was performed. The average number of lymph nodes removed was 13.49 .

False positive results were found in 11 (8.4\%) of the 131 aspiration cytology examinations in patients not receiving neoadjuvant therapy. Based on a final histological examination of the ALNs, 76 patients (58\%) were confirmed to be stage N0-1 and 55 patients (42\%) were stage $\mathrm{N} 2-3$.

No significant correlation was found between preoperatively assessable clinicopathological parameters and axillary lymph node status for patients not receiving neoadjuvant therapy (Tables 1 and 2).

Neoadjuvant therapy was administered in 59 cases, and in 23 (39\%) of these cases, complete axillary pathological remission was confirmed. Based on a final histological examination of the axillary lymph nodes, 40 patients (68\%) were in stage N0-1 and 19 patients (32\%) were in stage $\mathrm{N} 2-3$.

The results of the histological examinations, the immunohistochemical status and the number of positive lymph nodes detected by ultrasound examination showed no correlation to the final histological status of the lymph node. If preoperative ultrasound examinations find that the primary breast tumour is $\leq 20 \mathrm{~mm}$ $(\mathrm{p}=0.002)$ or the positive lymph node is $\leq 15 \mathrm{~mm}(\mathrm{p}=0.04)$, the status of the axillary lymph nodes will likely be stage N0-1; therefore, a maximum of 3 positive axillary lymph nodes are present (Tables 3 and 4). Similarly, in patients with triple negative breast cancer (TNBC) who receive neoadjuvant therapy, if the size of the tumour is $\leq 20 \mathrm{~mm}$, the axillary lymph node status is NO-1 in $87.5 \%$ of the patients $(\mathrm{p}<0.001)$ (Table 3$)$.

We examined the likelihood of stage N0-1 in the presence of two preoperative factors: $\mathrm{a} \leq 20 \mathrm{~mm}$ tumour size as measured by ultrasound and a $\leq 15 \mathrm{~mm}$ size of the lymph node considered metastatic. In the patient group not receiving neoadjuvant therapy $(\mathrm{p}=0.948)$, this could not be confirmed; however, in patients receiving neoadjuvant therapy, the likelihood of no more than 3 metastatic lymph nodes is very high $(\mathrm{p}=0.01)$.

Logistic regression was used to examine which variables are predictive of axillary status. Using the omnibus test, we found that the independent variables in the model are more related to the dependent variable than we would expect due to chance $(\mathrm{p}<0.001)$. We were able to confirm that the size of the tumour $(\operatorname{Exp}(\mathrm{B})=1.050,95 \% \mathrm{CI}=1.016-1.085, \mathrm{p}=0.004)$ is predictive of axillary status. The resulting model was statistically significant $(\chi$ $[2]=18.806, \mathrm{df}=3, \mathrm{p}<0.001)$. The proportion of cases categorized
Table 2

Relation of preoperative pathological factors to final lymph node disease burden in patients not receiving neoadjuvant therapy $-\mathrm{II}-$ Chi square test.

\begin{tabular}{llll}
\hline Neoadj. 0 & $\mathrm{N} 0-1(\mathrm{n}=76)$ & $\mathrm{N} 2-3(\mathrm{n}=55)$ & $\mathrm{p}$ value \\
\hline ER & $\mathrm{n}=76$ & $\mathrm{n}=55$ & 0.281 \\
positive & $47(61.84 \%)$ & $39(70.91 \%)$ & \\
negative & $29(38.16 \%)$ & $16(29.09 \%)$ & \\
PR & $\mathrm{n}=76$ & $\mathrm{n}=55$ & 0.305 \\
positive & $43(56.58 \%)$ & $36(65.45 \%)$ & \\
negative & $33(43.42 \%)$ & $19(34.55 \%)$ & \\
Ki67 & $\mathrm{n}=76$ & $\mathrm{n}=55$ & 0.845 \\
positive & $64(84.21 \%)$ & $47(85.45 \%)$ & \\
negative & $12(15.79 \%)$ & $8(14.55 \%)$ & \\
Topoiz. & $\mathrm{n}=76$ & $\mathrm{n}=55$ & 0.883 \\
positive & $60(78.95 \%)$ & $44(80 \%)$ & \\
negative & $16(21.05 \%)$ & $11(20 \%)$ & \\
HER-2 & $\mathrm{n}=76$ & $\mathrm{n}=55$ & 0.883 \\
positive & $16(21.05 \%)$ & $11(20 \%)$ & \\
negative & $60(78.95 \%)$ & $44(80 \%)$ & \\
TNBC & $\mathrm{n}=76$ & $\mathrm{n}=55$ & 0.672 \\
yes & $19(25 \%)$ & $12(21.8 \%)$ & \\
no & $57(75 \%)$ & $43(78.2 \%)$ & \\
Tumour histology on biopsy & $\mathrm{n}=76$ & $\mathrm{n}=55$ & 0.871 \\
Ductal & $48(63.16 \%)$ & $33(60 \%)$ & \\
Lobular & $4(5.26 \%)$ & $4(7.27 \%)$ & \\
Other invasive & $24(31.58 \%)$ & $18(32.73 \%)$ & \\
Histologic grade & $\mathrm{n}=65$ & $\mathrm{n}=51$ & 0.576 \\
I & $2(3.08 \%)$ & $3(5.88 \%)$ & \\
II & $27(41.54 \%)$ & $24(47.06 \%)$ & \\
III & $36(55.38 \%)$ & $24(47.06 \%)$ & \\
\hline & & & \\
& & &
\end{tabular}

correctly was $69.4 \%$ (overall percentage) with this model, leading to a more precise result compared to categorizing by chance (55.4\%).

Cases with no more than 2 (Z1) or 3 or more lymph nodes (Z2) were compared to the preoperatively assessable factors in patients grouped by receiving or not receiving neoadjuvant therapy. In patients not receiving neoadjuvant therapy, the size of the breast tumour, axillary status and clinicopathological characteristics of the tumour showed no correlation to the final histological status of the axilla (data not shown).

In patients receiving neoadjuvant therapy, the possibility of no more than 2 metastatic lymph nodes is very high $(70.58 \%)$ if the size of the tumour is $\leq 20 \mathrm{~mm}(\mathrm{p}=0.008)$ based on the ultrasound examination, and this proportion is much higher $(85.71 \%)$ in patients with TNBC $(\mathrm{p}=0.002)$. The joint presence of two preoperatively assessable factors $-\leq 20 \mathrm{~mm}$ tumour size confirmed by ultrasound and a $\leq 15 \mathrm{~mm}$ size of the lymph node considered metastatic - only increased the possibility of no more than 2 positive lymph nodes in patients receiving neoadjuvant therapy

Table 1

Relation of preoperative imaging results to final lymph node disease burden in patients not receiving neoadjuvant therapy $-\mathrm{I}-\mathrm{Chi}$ square test.

\begin{tabular}{|c|c|c|c|}
\hline Neoadj. 0 & N0-1 $(n=76)$ & $\mathrm{N} 2-3(\mathrm{n}=55)$ & $\mathrm{p}$ value \\
\hline Tumour size on imaging & $\mathrm{n}=76$ & $\mathrm{n}=55$ & 0.703 \\
\hline$\leq 20 \mathrm{~mm}$ & $44(57.9 \%)$ & $30(54.5 \%)$ & \\
\hline$>20 \mathrm{~mm}$ & $32(42.1 \%)$ & $25(45.5 \%)$ & \\
\hline Tumour size on imaging (TNBC) & $\mathrm{n}=19$ & $\mathrm{n}=12$ & 0.981 \\
\hline$\leq 20 \mathrm{~mm}$ & $11(57.9 \%)$ & $7(58.3 \%)$ & \\
\hline$>20 \mathrm{~mm}$ & $8(42.1 \%)$ & $5(41.7 \%)$ & \\
\hline Lymph node size on imaging & $\mathrm{n}=68$ & $\mathrm{n}=48$ & 0.979 \\
\hline$\leq 15 \mathrm{~mm}$ & $31(45.6 \%)$ & $22(45.8 \%)$ & \\
\hline$>15 \mathrm{~mm}$ & $37(54.4 \%)$ & $26(54.2 \%)$ & \\
\hline Lymph node size on imaging (TNBC) & $\mathrm{n}=17$ & $\mathrm{n}=11$ & 0.453 \\
\hline$\leq 15 \mathrm{~mm}$ & $7(41.17 \%)$ & $3(27.27 \%)$ & \\
\hline$>15 \mathrm{~mm}$ & $10(58.83 \%)$ & $8(72.73 \%)$ & \\
\hline Tumour $\leq 20 \mathrm{~mm}$ and lymph node $\leq 15 \mathrm{~mm}$ & $\mathrm{n}=31$ & $\mathrm{n}=22$ & 0.948 \\
\hline Number of abnormal lymph nodes on axillary ultrasound & $\mathrm{n}=76$ & $\mathrm{n}=55$ & 0.338 \\
\hline 1 & $65(85.53 \%)$ & $43(78.18 \%)$ & \\
\hline$>1$ & $11(14.47 \%)$ & $12(21.82 \%)$ & \\
\hline
\end{tabular}


Table 3

Relation of preoperative imaging results to final lymph node disease burden in patients receiving neoadjuvant therapy $-\mathrm{I}-\mathrm{Chi}$ square test.

\begin{tabular}{|c|c|c|c|}
\hline Neoadj. & No-1 $(n=40)$ & $\mathrm{N} 2-3(\mathrm{n}=19)$ & $\mathrm{p}$ value \\
\hline Tumour size on imaging & $\mathrm{n}=40$ & $\mathrm{n}=19$ & 0.002 \\
\hline$\leq 20 \mathrm{~mm}$ & $28(70 \%)$ & $5(26.32 \%)$ & \\
\hline$>20 \mathrm{~mm}$ & $12(30 \%)$ & $14(73.68 \%)$ & \\
\hline Tumour size on imaging (TNBC) & $\mathrm{n}=16$ & $\mathrm{n}=7$ & $<0.001$ \\
\hline$\leq 20 \mathrm{~mm}$ & $14(87.5 \%)$ & $0(0 \%)$ & \\
\hline$>20 \mathrm{~mm}$ & $2(12.5 \%)$ & $7(100 \%)$ & \\
\hline Lymph node size on imaging & $\mathrm{n}=31$ & $\mathrm{n}=13$ & 0.04 \\
\hline$\leq 15 \mathrm{~mm}$ & $20(64.51 \%)$ & $4(30.77 \%)$ & \\
\hline$>15 \mathrm{~mm}$ & $11(35.49 \%)$ & $9(69.23 \%)$ & \\
\hline Lymph node size on imaging (TNBC) & $\mathrm{n}=12$ & $\mathrm{n}=6$ & 0.737 \\
\hline$\leq 15 \mathrm{~mm}$ & $5(41.67 \%)$ & $3(50 \%)$ & \\
\hline$>15 \mathrm{~mm}$ & $7(58.33 \%)$ & $3(50 \%)$ & \\
\hline Tumour $\leq 20 \mathrm{~mm}$ and lymph node $\leq 15 \mathrm{~mm}$ & $\mathrm{n}=20$ & $\mathrm{n}=4$ & 0.01 \\
\hline Number of abnormal lymph nodes on axillary ultrasound & $\mathrm{n}=40$ & $\mathrm{n}=19$ & 0.161 \\
\hline 1 & $38(95 \%)$ & $15(78.95 \%)$ & \\
\hline$>1$ & $2(5 \%)$ & $4(21.05 \%)$ & \\
\hline
\end{tabular}

\section{Table 4}

Relation of preoperative pathological factors to final lymph node disease burden in patients receiving neoadjuvant therapy - II - Chi square test.

\begin{tabular}{|c|c|c|c|}
\hline Neoadj. & No-1 $(n=40)$ & $\mathrm{N} 2-3(\mathrm{n}=19)$ & $\mathrm{p}$ value \\
\hline ER & $\mathrm{n}=40$ & $\mathrm{n}=19$ & 0.361 \\
\hline positive & $16(40 \%)$ & $10(52.63 \%)$ & \\
\hline negative & $24(60 \%)$ & $9(47.37 \%)$ & \\
\hline PR & $\mathrm{n}=40$ & $\mathrm{n}=19$ & 0.432 \\
\hline positive & $7(17.5 \%)$ & $5(26.32 \%)$ & \\
\hline negative & $33(82.5 \%)$ & $14(73.68 \%)$ & \\
\hline Ki67 & $\mathrm{n}=40$ & $\mathrm{n}=19$ & 0.551 \\
\hline positive & $31(77.5 \%)$ & $16(84.22 \%)$ & \\
\hline negative & $9(22.5 \%)$ & $3(15.78 \%)$ & \\
\hline Topoiz. & $\mathrm{n}=40$ & $\mathrm{n}=19$ & 0.305 \\
\hline positive & $24(60 \%)$ & $14(73.68 \%)$ & \\
\hline negative & $16(40 \%)$ & $5(26.32 \%)$ & \\
\hline HER-2 & $\mathrm{n}=40$ & $\mathrm{n}=19$ & 0.323 \\
\hline positive & $11(27.5 \%)$ & $3(15.78 \%)$ & \\
\hline negative & $29(72.5 \%)$ & $16(84.22 \%)$ & \\
\hline TNBC & $\mathrm{n}=40$ & $\mathrm{n}=19$ & 0.816 \\
\hline yes & $16(40 \%)$ & $7(36.84 \%)$ & \\
\hline no & $24(60 \%)$ & $12(63.16 \%)$ & \\
\hline Tumour histology on biopsy & $\mathrm{n}=40$ & $\mathrm{n}=19$ & 0.314 \\
\hline Ductal & $29(72.5 \%)$ & $14(73.69 \%)$ & \\
\hline Lobular & $0(0 \%)$ & $1(5.26 \%)$ & \\
\hline Other invasive & $11(27.5 \%)$ & $4(21.05 \%)$ & \\
\hline Histologic grade & $\mathrm{n}=32$ & $\mathrm{n}=18$ & 0.157 \\
\hline I & $5(15.62 \%)$ & $0(0 \%)$ & \\
\hline II & $12(37.5 \%)$ & $6(33.33 \%)$ & \\
\hline III & $15(46.88 \%)$ & $12(66.67 \%)$ & \\
\hline
\end{tabular}

( $\mathrm{p}=0.728$ vs. $\mathrm{p}=0.017$ ) (Table 5 ).

The final lymph node status of the axilla showed no relation to other clinicopathological characteristics (data not shown).

\section{Discussion}

ALND has been the standard procedure in the surgical treatment of malignant breast tumours for at least 100 years, with significant changes occurring in recent years. SLNB [14] can be used to avoid ALND in a significant proportion of patients; therefore, morbidity of surgical treatment of early breast cancers can be decreased significantly [15-17]. At first, if preoperative examinations found no metastasis but the intraoperative or final histological examination confirmed metastasis in the SLN, ALND was considered necessary. Later, clinical studies confirmed that even the presence of micrometastasis or an isolated tumour cell in a lymph node is sufficient to indicate SLNB $[18,19]$. The result of the ACOSOG Z0011 study was a milestone. This study concluded that even in cases with a maximum of two positive lymph nodes containing macrometastasis, ALND may be avoided if the patient meets the inclusion criteria for the study [1,2]. Moreover, based on the results of the AMAROS study, ALND may also be avoided in patients who have undergone a mastectomy and have a SLN with confirmed metastasis; irradiation of the axillary region and close follow-up are sufficient [20].

Nowadays, the effort to further limit the indication area of ALND accompanied by significant morbidity is completely reasonable. One way to do this is to preoperatively screen patients only at stage N1 axillary status. Based on several international guidelines, a sentinel lymph node biopsy should be performed in cases characterised by the presence of axillary lymph nodes considered negative by preoperative examinations and aspiration cytology or core biopsy should be performed with axillary lymph nodes considered positive $[3,4,21,22]$. Several research groups have studied which factors detected or examined during the preoperative period (imaging studies, histological finding etc.) may be suitable to determine whether SLNB or ALND should be performed during surgery $[13,23,24]$. In the post-Z0011 period of the treatment of breast tumours, not only the presence of axillary metastasis is examined, but positive cases are also differentiated as mild (lymph node status N1 and 1 to 3 positive lymph nodes) and severe (lymph node status N2 and 4 or more positive lymph nodes) axillary metastases. Lim et al. confirmed that if the patient meets the criteria for the Z0011 study and the axillary ultrasound detects 3 or more positive lymph nodes, it is very likely that there are multiple positive lymph nodes in the axilla; therefore, ALND cannot be avoided [23]. This result has also been confirmed by Liu et al., who found that ALND may be avoided if patients meet the Z0011 study criteria and the axillary ultrasound examination confirms only one suspected metastatic lymph node [25]. If two lymph nodes are considered metastatic based on an ultrasound examination, histological sampling and axillary lymph node dissection are recommended. Liang et al. highlight the importance of a preoperative histological examination; the authors have shown that in cases where axillary lymph nodes are found to be positive with fine needle aspiration cytology, the patient is more likely to have more than 3 metastatic lymph nodes in the axilla, compared to cases where the sentinel lymph node biopsy confirms 1 to 2 metastatic lymph nodes [26].

In our study, we examined which combination of preoperative parameters would allow axillary lymph node dissection to be avoided if axillary lymph node involvement is confirmed preoperatively. We also examined which of these clinicopathological characteristics could eliminate the need for this radical surgical intervention. Based on our results, the severity of the involvement 
Table 5

Relation of imaging results to modified final lymph node disease burden (Z1 or Z2) in patients receiving neoadjuvant therapy - I - Chi square test.

\begin{tabular}{|c|c|c|c|}
\hline Neoadj. & $\mathrm{Z1}(\mathrm{n}=34)$ & $\mathrm{Z2}(\mathrm{n}=25)$ & $\mathrm{p}$ value \\
\hline Tumour size on imaging & $\mathrm{n}=34$ & $\mathrm{n}=25$ & 0.008 \\
\hline$\leq 20 \mathrm{~mm}$ & $24(70.58 \%)$ & $9(36 \%)$ & \\
\hline$>20 \mathrm{~mm}$ & $10(29.42 \%)$ & $16(64 \%)$ & \\
\hline Tumour size on imaging (TNBC) & $\mathrm{n}=14$ & $\mathrm{n}=9$ & 0.002 \\
\hline$\leq 20 \mathrm{~mm}$ & $12(85.71 \%)$ & $2(22.22 \%)$ & \\
\hline$>20 \mathrm{~mm}$ & $2(14.29 \%)$ & $7(77.78 \%)$ & \\
\hline Lymph node size on imaging & $\mathrm{n}=28$ & $\mathrm{n}=16$ & 0.086 \\
\hline$\leq 15 \mathrm{~mm}$ & $18(64.29 \%)$ & $6(37.5 \%)$ & \\
\hline$>15 \mathrm{~mm}$ & $10(35.71 \%)$ & $10(62.5 \%)$ & \\
\hline Lymph node size on imaging (TNBC) & $\mathrm{n}=11$ & $\mathrm{n}=7$ & 0.914 \\
\hline$\leq 15 \mathrm{~mm}$ & $5(45.45 \%)$ & $3(42.86 \%)$ & \\
\hline$>15 \mathrm{~mm}$ & $6(54.55 \%)$ & $4(57.14 \%)$ & \\
\hline Tumour $\leq 20 \mathrm{~mm}$ and lymph node $\leq 15 \mathrm{~mm}$ & $\mathrm{n}=18$ & $\mathrm{n}=6$ & 0.017 \\
\hline Number of abnormal lymph nodes on axillary ultrasound & $\mathrm{n}=34$ & $\mathrm{n}=25$ & 0.177 \\
\hline 1 & $33(97.06 \%)$ & $20(80 \%)$ & \\
\hline$>1$ & $1(2.94 \%)$ & $5(20 \%)$ & \\
\hline
\end{tabular}

of the axillary region in the tumour process could not be clearly predicted preoperatively with the clinicopathological characteristics of the tumour in patients not receiving neoadjuvant therapy. In contrast, a recent study confirmed that primary ALND is not necessary and SLNB is recommended if the preoperative breast ultrasound confirms a $2 \mathrm{~cm}$ or smaller primary tumour in the breast, no more than one positive lymph node is confirmed with aspiration cytology, and the patient does not receive neoadjuvant therapy [13]. In another retrospective study, Lloyd et al. also found that patients are very likely to have no more than 2 axillary lymph nodes with macrometastasis if the preoperative ultrasound confirmed a $20 \mathrm{~mm}$ or smaller primary tumour, histology of this tumour confirmed invasive ductal or lobular carcinoma, and breastconserving surgery was performed. Therefore, in these cases, ALND represents overtreatment [24].

Based on our study, we claim that lymph node status N0-1 in patients not receiving neoadjuvant therapy cannot be determined with certainty with preoperative examinations, while the lymph node status of patients receiving neoadjuvant chemotherapy can be predicted with great certainty based on the results of the preoperative ultrasound examination. If patients also receive neoadjuvant therapy, it can be predicted with high probability whether the disease is in stage N0-1 or not and whether ALND can be avoided or not based on the preoperative size of the tumour $(<20 \mathrm{~mm}, \mathrm{p}=0.002)$ and the preoperative size of the lymph node $(<15 \mathrm{~mm}, \mathrm{p}=0.04)$.

In patients with breast tumours, the lymph node status of the axilla plays a key role in planning local and systemic therapy. If there is a metastatic lymph node in the axilla, a significant proportion of patients receive neoadjuvant systemic therapy, which resolves the axillary metastatic process in approximately $40 \%$ of cases [27]. Following neoadjuvant therapy, the standard surgical procedure in these patients was ALND even in cases with complete pathological remission. Several studies have addressed the question of sentinel lymph node biopsy and repeated biopsy after neoadjuvant therapy [28]. In the ACOSOG Z1071 study, the rate of false negative sentinel lymph node biopsies was close to $10 \%$ false negative (12.6\%), and this value further decreased with the removal of the lymph node indicated with a marker (metal clip) during axillary core biopsy. During surgical intervention, the SLN is already detected using the classical dual tracer method (technetium 99mlabelled human colloidal albumin and blue dye). With this technique (targeted axillary dissection, TAD), the rate of false negative sentinel lymph nodes decreased to approximately $2 \%$ [27,29-31]. Pilewski et al. analysed data from 425 patients and studied the extent to which preoperative imaging studies influence the lymph node status of the axilla [32,33]. If the examinations suggested the presence of a metastatic lymph node and the patient met the criteria for the Z0011 study, axillary lymph node dissection could have been avoided in $71 \%$ of cases. If aspiration cytology was positive, ALND was unnecessary in $45 \%$ of cases. A Spanish study published in 2018 also investigated whether axillary lymph node dissection should be performed after neoadjuvant therapy in cases where an axillary lymph node is considered positive with aspiration cytology [34]. In cases showing a significant presence of the HER2 receptor and low expression of the oestrogen receptor, there is a high chance that complete pathological remission will occur, and in these cases, ALND was not recommended. Our analyses confirmed the same result. Following neoadjuvant therapy, no more than 3 and no more than 2 positive lymph nodes were confirmed, respectively, with the final histology in two-thirds (40/ $59,68 \%)$ and in over $50 \%(34 / 59,57 \%)$ of the cases, respectively; therefore, axillary lymph node dissection could have been avoided.

Data from 3398 patients were reviewed in a meta-analysis, and the authors aimed to see whether ALND is necessary after neoadjuvant therapy in lymph node-positive breast tumour cases [10]. According to the analysis, the recommended treatment strategy at present is ALND. However, optimizing preoperative examinations and screening the patient population may help to achieve a more precise preoperative evaluation of axillary lymph node status. In the future, performing SLNB with the dual tracer method and labelling the positive axillary lymph node in advance with a metal clip or with a radiopharmaceutical containing iodine followed by removing the labelled lymph node may decrease the number of axillary lymph node dissections. Based on the analysis, HER2positive and triple receptor-negative cases by immunochemistry require further research. A study published in 2017 showed that the efficacy of neoadjuvant therapy did not differ in these cases, but further studies are recommended in these cases as well [11]. Our study also showed, in patients with triple negative breast cancer (TNBC) who receive neoadjuvant therapy, if the size of the tumour is $\leq 20 \mathrm{~mm}$, the axillary lymph node status is N0-1 in $87.5 \%$ of the patients. The same result was found in a study; ALND could be avoided after neoadjuvant therapy in $48 \%$ of the patients, especially in the case of HER2 receptor-positive and triple receptor-negative cases [12]. The study supported performing SLNB in patients with a breast tumour receiving neoadjuvant therapy and with multiple axillary lymph node metastases as well. Longer studies are required to confirm the results. A retrospective study that processed data from 1944 patients confirms this result; the study concluded that if patients receive neoadjuvant therapy followed by a mastectomy and if the receptor status is HER2-positive and triple receptor- 
negative, ALND could most likely have been avoided [35].

\section{Conclusions}

Our results show that detecting suspicious lymph nodes by axillary ultrasound examination may predict the stage of the disease; therefore, we consider a complete examination of the axilla important in ruling out potential lymph node metastases. Our results confirm that in patients receiving neoadjuvant therapy, in addition to the preoperative size of the tumour $(<20 \mathrm{~mm}$, $\mathrm{p}=0.002)$, the preoperative size of the lymph node $(<15 \mathrm{~mm}$, $\mathrm{p}=0.04$ ) may also be used to predict that the stage of the disease is N0-1. In these cases, sentinel lymph node biopsy with or without radiation therapy and close follow-up may serve as adequate therapy.

\section{Funding statement}

None.

\section{Ethics}

The study was registered at the University of Szeged with the identifier 20/2017-SZTE.

\section{Declaration of competing interest}

The authors have no conflict of interest or financial disclose.

\section{Acknowledgments}

We wish to acknowledge Júlia Nagy, Letícia Frittmann, Dóra Szirony, Dóra Nagyszegi and Donát Berki for their dedicated work in collecting the data which made the execution of this study possible.

\section{References}

[1] Giuliano AE, Hunt KK, Ballman KV, Beitsch PD, Whitworth PW, Blumencranz PW, et al. Axillary dissection vs no axillary dissection in women with invasive breast cancer and sentinel node metastasis: a randomized clinical trial. J Am Med Assoc 2011;305:569-75. https://doi.org/10.1001/ jama.2011.90.

[2] Giuliano AE, Ballman KV, McCall L, Beitsch PD, Brennan MB, Kelemen PR, et al. Effect of axillary dissection vs No axillary dissection on 10-year overall survival among women with invasive breast cancer and sentinel node metastasis: the ACOSOG Z0011 (Alliance) randomized clinical trial. J Am Med Assoc 2017;318:918-26. https://doi.org/10.1001/jama.2017.11470.

[3] Untch M, Huober J, Jackisch C, Schneeweiss A, Brucker SY, Dall P, et al. Initial treatment of patients with primary breast cancer: evidence, controversies, consensus: spectrum of opinion of German specialists at the 15th International St. Gallen Breast Cancer Conference (Vienna 2017). Geburtshilfe Frauenheilkd 2017;77:633-44. https://doi.org/10.1055/s-0043-111601.

[4] Lázár G, Bursics A, Farsang Z, Harsányi L, Kósa C, Maráz R, et al. 3rd Hungarian breast cancer consensus conference - surgery guidelines. Magy Onkol 2016;60:194-207. Epub 2016 Jul 8. PMID: 27579720.

[5] Helfgott R, Mittlböck M, Miesbauer M, Moinfar F, Haim S, Mascherbauer M, et al. The influence of breast cancer subtypes on axillary ultrasound accuracy: a retrospective single center analysis of 583 women. Eur J Surg Oncol 2019;45:538-43. https://doi.org/10.1016/j.ejso.2018.10.001.

[6] Topps AR, Barr SP, Pikoulas P, Pritchard SA, Maxwell AJ. Pre-operative axillary ultrasound-guided needle sampling in breast cancer: comparing the sensitivity of fine needle aspiration cytology and core needle biopsy. Ann Surg Oncol 2018;25:148-53. https://doi.org/10.1245/s10434-017-6090-1.

[7] Vidya R, Iqbal FM, Bickley B. Pre-operative axillary staging: should core biopsy be preferred to fine needle aspiration cytology? Ecancermedical Sci. 2017;7: 724. https://doi.org/10.3332/ecancer.2017.724.eCollection.2017. Published online 2017 Mar 7.

[8] Vijayaraghavan GR, Vedantham S, Kataoka M, DeBenedectis C, Quinlan RM. The relevance of ultrasound imaging of suspicious axillary lymph nodes and fine-needle aspiration biopsy in the post-ACOSOG Z11 era in early breast cancer. Acad Radiol 2017;24:308-15. https://doi.org/10.1016/ j.acra.2016.10.005.

[9] Zhu Y, Zhou W, Zhou JQ, Fei XC, Ye TJ, Huang O, et al. Axillary staging of early- stage invasive breast cancer by ultrasound-guided fine-needle aspiration cytology: which ultrasound criteria for classifying abnormal lymph nodes should be adopted in the post-ACOSOG Z0011 trial era? J Ultrasound Med 2016;35:885-93. https://doi.org/10.7863/ultra.15.06019.

[10] El Hage Chehade H, Headon H, El Tokhy O, Heeney J, Kasem A, Mokbel K. Is sentinel lymph node biopsy a viable alternative to complete axillary dissection following neoadjuvant chemotherapy in women with node-positive breast cancer at diagnosis? An updated meta-analysis involving 3,398 patients. Am J Surg 2016;212:969-81. https://doi.org/10.1016/ j.amjsurg.2016.07.018.

[11] Tadros AB, Yang WT, Krishnamurthy S, Rauch GM, Smith BD, Valero V, et al Identification of patients with documented pathologic complete response in the breast after neoadjuvant chemotherapy for omission of axillary surgery. JAMA Surg 2017;152:665-70. https://doi.org/10.1001/jamasurg.2017.0562.

[12] Mamtani A, Barrio AV, King TA, Van Zee KJ, Plitas G, Pilewskie M, et al. How often does neoadjuvant chemotherapy avoid axillary dissection in patients with histologically confirmed nodal metastases? Results of a prospective study. Ann Surg Oncol 2016;23:3467-74. https://doi.org/10.1245/s10434016-5246-8.

[13] Harris CK, Tran HT, Lee K, Mylander C, Pack D, Rosman M, et al. Positive Ultrasound-guided lymph node needle biopsy in breast cancer may not mandate axillary lymph node dissection. Ann Surg Oncol 2017;24:3004-10. https://doi.org/10.1245/s10434-017-5935-y.

[14] Krag DN, Weaver DL, Alex JC, Fairbank JT. Surgical resection and radiolocalization of the sentinel lymph node in breast cancer using a gamma probe. Surg Oncol 1993;2:335-9. discussion 340. PMID: 8130940.

[15] Guenther JM, Hansen NM, DiFronzo LA, Giuliano AE, Collins JC, Grube BL, et al. Axillary dissection is not required for all patients with breast cancer and positive sentinel nodes. Arch Surg 2003;138:52-6. https://doi.org/10.1001/ archsurg.138.1.52.

[16] Jeruss JS, Winchester DJ, Sener SF, Brinkmann EM, Bilimoria MM, Barrera Jr E et al. Axillary recurrence after sentinel node biopsy. Ann Surg Oncol 2005;12: 34-40. https://doi.org/10.1007/s10434-004-1164-2.

[17] Krag DN, Anderson SJ, Julian TB, Brown AM, Harlow SP, Costantino JP, et al. Sentinel-lymph-node resection compared with conventional axillary-lymphnode dissection in clinically node-negative patients with breast cancer: overall survival findings from the NSABP B-32 randomised phase 3 trial Lancet Oncol 2010;11:927-33. https://doi.org/10.1016/S1470-2045(10) 70207-2.

[18] Galimberti V, Cole BF, Viale G, Veronesi P, Vicini E, Intra M, et al. International Breast Cancer Study Group Trial 23-01. Axillary dissection versus no axillary dissection in patients with breast cancer and sentinel-node micrometastases (IBCSG 23-01): 10-year follow-up of a randomised, controlled phase 3 trial Lancet Oncol 2018 Oct;19(10):1385-93. https://doi.org/10.1016/S14702045(18)30380-2.

[19] Solá M, Alberro JA, Fraile M, Santesteban P, Ramos M, Fabregas R, et al Complete axillary lymph node dissection versus clinical follow-up in breast cancer patients with sentinel node micrometastasis: final results from the multicenter clinical trial AATRM 048/13/2000. Ann Surg Oncol 2013;20: 120-7. https://doi.org/10.1245/s10434-012-2569-y.

[20] Donker M, van Tienhoven G, Straver ME, Meijnen P, van de Velde CJ Mansel RE, et al. Radiotherapy or surgery of the axilla after a positive sentinel node in breast cancer (EORTC 10981-22023 AMAROS): a randomised, multicentre, open-label, phase 3 non-inferiority trial. Lancet Oncol 2014;15: 1303-10. https://doi.org/10.1016/S1470-2045(14)70460-7.

[21] Gradishar WJ, Anderson BO, Balassanian R, Blair SL, Burstein HJ, Cyr A, et al NCCN guidelines insights: breast cancer, version 1.2017. J Natl Compr Cancer Netw 2017;15:433-51. PMID: 28404755.

[22] Cardoso F, Senkus E, Costa A, Papadopoulos E, Aapro M, André F, et al. 4th ESO-ESMO international consensus guidelines for advanced breast cancer (ABC 4)†. Ann Oncol 2018;29:1634-57. https://doi.org/10.1093/annonc/ mdy192.

[23] Lim GH, Upadhyaya VS, Acosta HA, Lim JMA, Allen Jr JC, Leong LCH. Preoperative predictors of high and low axillary nodal burden in Z0011 eligible breast cancer patients with a positive lymph node needle biopsy result. Eur J Surg Oncol 2018;44:945-50. https://doi.org/10.1016/j.ejso.2018.04.003.

[24] Lloyd P, Theophilidou E, Newcombe RG, Pugh L, Goyal A. Axillary tumour burden in women with a fine-needle aspiration/core biopsy-proven positive node on ultrasonography compared to women with a positive sentinel node. Br J Surg 2017;104:1811-5. https://doi.org/10.1002/bjs.10661.

[25] Liu Miao, Yang Yang, Xie Fei, Guo Jiagia, Wang Siyuan, Yang Houpu, et al Could axillary clearance be avoided in clinically node-negative breast cancer patients with positive nodes diagnosed by ultrasound guided biopsy in the post-ACOSOG Z0011 era? PLoS One 2019;14:e0210437. https://doi.org/ 10.1371/journal.pone.0210437. Published online 2019 Jan 10.

[26] Liang Y, Chen X, Tong Y, Zhan W, Zhu Y, Wu J, et al. Higher axillary lymph node metastasis burden in breast cancer patients with positive preoperative node biopsy: may not be appropriate to receive sentinel lymph node biopsy in the post-ACOSOG Z0011 trial era. World J Surg Oncol 2019;17:37. https:// doi.org/10.1186/s12957-019-1582-z.

[27] Boughey JC, Suman VJ, Mittendorf EA, Ahrendt GM, Wilke LG, Taback B, et al Alliance for Clinical Trials in Oncology. Sentinel lymph node surgery after neoadjuvant chemotherapy in patients with node-positive breast cancer: the ACOSOG Z1071 (Alliance) clinical trial. J Am Med Assoc 2013;310:1455-61. https://doi.org/10.1001/jama.2013.278932. 
[28] Kuehn T, Bauerfeind I, Fehm T, Fleige B, Hausschild M, Helms G, et al. Sentinellymph-node biopsy in patients with breast cancer before and after neoadjuvant chemotherapy (SENTINA): a prospective, multicentre cohort study. Lancet Oncol 2013;14:609-18. https://doi.org/10.1016/S1470-2045(13) 70166-9.

[29] Caudle AS, Yang WT, Krishnamurthy S, Mittendorf EA, Black DM, Gilcrease MZ et al. Improved axillary evaluation following neoadjuvant therapy for patients with nodepositive breast cancer using selective evaluation of clipped nodes: implementation of targeted axillary dissection. J Clin Oncol 2016;34:1072-8. https://doi.org/10.1200/JCO.2015.64.0094.

[30] Caudle AS, Yang WT, Mittendorf EA, Black DM, Hwang R, Hobbs B, et al. Selective surgical localization of axillary lymph nodes containing metastases in patients with breast cancer: a prospective feasibility trial. JAMA Surg 2015;150:137-43. https://doi.org/10.1001/jamasurg.2014.1086.

[31] Boughey JC, Ballman KV, Le-Petross HT, McCall LM, Mittendorf EA Ahrendt GM, et al. Identification and resection of clipped node decreases the false-negative rate of sentinel lymph node surgery in patients presenting with node-positive breast cancer (T0-T4, N1-N2) who receive neoadjuvant chemotherapy: results from ACOSOG Z1071 (Alliance). Ann Surg 2016
Apr;263(4):802-7. https://doi.org/10.1097/SLA.0000000000001375.

[32] Pilewskie M, Mautner SK, Stempel M, Eaton A, Morrow M. Does a positive axillary lymph node needle biopsy result predict the need for an axillary lymph node dissection in clinically node-negative breast cancer patients in the ACOSOG Z0011 Era? Ann Surg Oncol 2016;23:1123-8. https://doi.org/ 10.1245/s10434-015-4944-y.

[33] Pilewskie M, Jochelson M, Gooch JC, Patil S, Stempel M, Morrow M. Is preoperative axillary imaging beneficial in identifying clinically node-negative patients requiring axillary lymph node dissection? J Am Coll Surg 2016;222: 138-45. https://doi.org/10.1016/j.jamcollsurg.2015.11.013.

[34] Osorio-Silla I, Gómez Valdazo A, Sánchez Méndez JI, York E, Díaz-Almirón M, Gómez Ramírez J, et al. Is it always necessary to perform an axillary lymph node dissection after neoadjuvant chemotherapy for breast cancer? Ann R Coll Surg Engl 2019;101:186-92. https://doi.org/10.1308/rcsann.2018.0196.

[35] Pilewskie M, Zabor EC, Mamtani A, Barrio A, Stempel M, Morrow M. The optimal treatment plan to avoid axillary lymph node dissection in early-stage breast cancer patients differs by surgical strategy and tumor subtype. Ann Surg Oncol 2017;24:3527-33. https://doi.org/10.1245/s10434-017-6016-y. 